\title{
Fishing in the NAFO Regulatory Area: Integrated Modeling of Resources, Social Impacts in Canada and EU Fleet Viability
}

\author{
Dan Lane \\ Telfer School of Management, University of Ottawa, \\ Ottawa, Ontario, Canada K1N 6N5 \\ E-mail: dlane@uOttawa.ca
}

Lane, D. Fishing in the NAFO regulatory area: Integrated modeling of resources, social impacts in Canada and EU fleet viability. J. Northw. Atl. Fish. Sci., 39: 119-145. doi:10.2960/J.v39.m586

\begin{abstract}
This paper presents an integrated spreadsheet model of the biological, social, and economic attributes of the international groundfishery on the Grand Banks in NAFO Divisions 3LNO. The historical involvement of the fisheries is traced from 1972 to the present. The model explores the impacts of the fishery on: (1) the status of six key Grand Banks groundfish stock populations, (2) the economics of the international commercial fishery, especially as experienced by Canada, Spain and Portugal, and (3) the social status of Atlantic Canadian coastal communities dependent on the Grand Banks fishery. Groundfish catches in the Grand Banks NAFO Regulatory Area (NRA) are used to estimate the implications on the annual integrated (harvesting and processing) economic performance of the fishing fleets. Social impacts of the fisheries on the labour opportunities in Canadian communities are also analysed. The integrated spreadsheet model is used to explore the impacts on stocks, fisheries, and communities under alternative assumptions about actual fishery removals. The results enable an improved understanding of the underlying historical behaviour of declining Northwest Atlantic groundfish stocks, economic viability from fishing, and the decline of Canadian coastal communities. Evidence from integrated modeling point out shortcomings associated with not knowing actual removals from fishing by NAFO contracting parties operating on the Grand Banks, and the need to establish better fisheries management data, control, and compliance in contrast to the uncertain gains from expending significant scientific effort on attempts to understand complex stochastic marine ecosystems as proposed in NAFO reform.
\end{abstract}

Key words: biological impacts, coastal communities, economy, ecosystem approach, fisheries management, fleet economic viability, Grand Banks, groundfisheries, integrated fisheries system, NAFO Regulatory Area (NRA), NAFO reform, social science

\section{Introduction}

Since 1979 when the organization was established, the Northwest Atlantic Fisheries Organization (NAFO) objective has been to contribute to the "optimum utilization, rational management and conservation of the fishery resources of the Convention Area" including the Grand Banks and the Flemish Cap off Newfoundland's east coast (Fig. 1 and www.nafo.int). Newfoundland history is linked to the Grand Banks groundfisheries, especially with the catch of Northern cod stocks. However, since the closure of the commercial Northern cod fisheries by Canada in 1992 and the subsequent demise of many groundfish stocks on the Grand Banks, the long and historical period of prosperous fisheries ended. Since this time, the Grand Banks fisheries have undergone an arduous period characterized by criticism of management difficulties and poor fishing practices among NAFO members.
Significant declines have taken place in the groundfish stocks on the Grand Banks not just in the NAFO Regulatory Area (NRA), the area managed by NAFO, but also in the Canadian portion of the Grand Banks. Excessive fishing effort coupled with the use of gear that captured large numbers of small fish put heavy pressure on groundfish stocks through the 1960s, 1970s and 1980s. Documented fishing practices of distant water fleets of groundfish trawlers operating in the NRA adjacent to Canada were unsustainable. These practices have ultimately contributed to the establishment of emergency moratoria that were declared on several stocks by the mid-1990s (NAFO, 1979-80, 1980-2002, 1991-2003).

Although Canada has had exclusive jurisdiction over its 200-mile Exclusive Economic Zone (EEZ) since 1977, biologically important areas of the Grand Banks immediately adjacent to the EEZ fall under international high seas management by NAFO. The "nose" (located in 


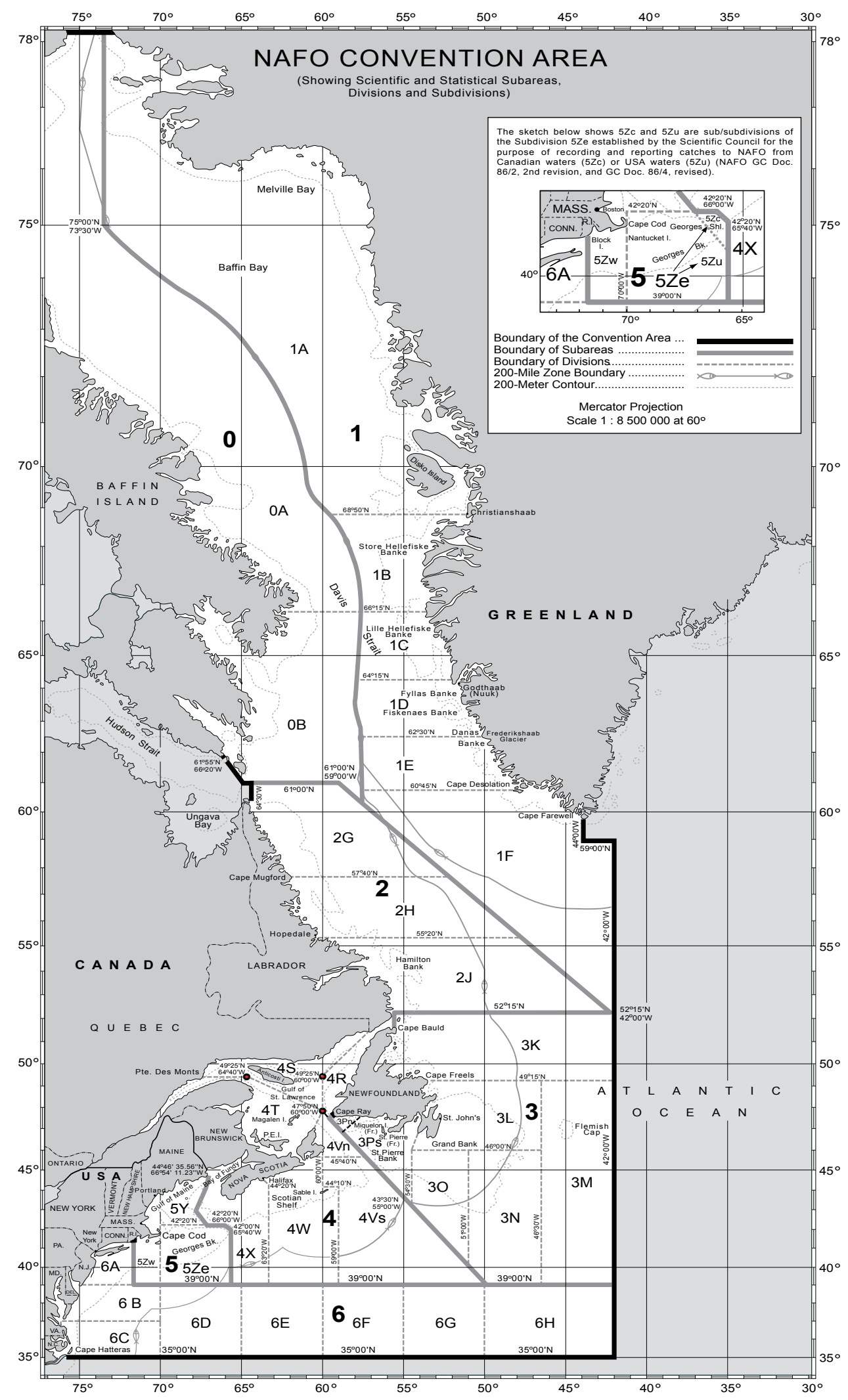

Fig. 1. Grand Banks Fishery Map showing NAFO Convention Area. The NAFO Regulatory Area is that part of the convention area outside the 200 limit. 
the eastern portion of Div. 3L, and the northern portion of Div. 3N) and "tail" (located in southern portions of Div. $3 \mathrm{~N}+3 \mathrm{O}$ ) of the Grand Banks (Fig. 1) are ecosystems where fish stocks straddle the artificial economic limit boundaries. The health of straddling groundfish stocks has direct relevance to the economic health of Atlantic fishing communities fishing in domestic waters adjacent to the EEZ boundaries on the Grand Banks (Lear, 2005). Historical over-fishing and illegal, unreported and unregulated (IUU) activities have continued to present NAFO with management problems for groundfish stocks that inhabit the Grand Banks NRA (Schmidt, 2005; Rayfuse, 2005).

Recently, reports from the World Wildlife Fund (WWF) and Greenpeace have taken direct aim at NAFO and its apparent inability to carry out its stock sustainability objectives. The reports universally call for further stock restrictions on fishing on the Grand Banks (McDiarmid et al., 2005; Rosenberg et al., 2005). As well, the first president of NAFO, Dr. Art May, was asked to provide the Canadian Minister of Fisheries and Oceans with advice on NAFO reform. In August 2005, Dr. May's advisory panel (May et al., 2005) recommended that the Government of Canada should act to replace NAFO with a new Regional Fisheries Management Organization (RFMO) and explicitly recognize the special interest of coastal states in the sustainable management of stocks. For its part, Canada has never acted on the findings of the panel within the ongoing discussions on NAFO reform. Canada has officially adopted NAFO reform via the scientific-based "ecosystem approach" (NAFO, MS 2007).

While a science-based "ecosystem approach" is seen as a means of reforming NAFO, there is at the same time considerable concern that NAFO appears unable to apply a precautionary approach to management decision making. Shelton (MS 2005) expresses concern for the case of Greenland halibut, "one of the last remaining commercially significant groundfish stocks in the Northwest Atlantic". He declares that the NAFO rebuilding plan is "considerably less cautious than one which would be specified under a precautionary approach". Moreover, he reminds us of the "lessons from the Northern cod disaster" and warns that under the current plan, the Greenland halibut stocks in the NAFO Convention area could be destroyed. This concern notes the lack of understanding of the drivers of the fishery system, and implicitly, the need to incorporate these drivers into a holistic evaluation of the impacts of fisheries management policy. Indeed, evidence suggests that understanding the integrated impacts of policy on the system is more important for realizing NAFO management objectives than is a complete scientific understanding of the underlying complex ecosystem (Swan and Gréboval, 2005).

Lane and Stephenson (1996) developed an integrated model for evaluating quantitative system impacts of fisheries management policy including stock impacts, fleet profit impacts, social conditions and the costs of management. Similarly, the OECD $(1997,2000)$ has undertaken fisheries management studies aimed at the "transition to responsible fisheries". In these studies, fishery systems models were developed to evaluate the biological as well as the social, economic, and administrative aspects of management policy toward determining effective fisheries management policies.

This paper uses the integrated modelling approaches referred to above to provide a framework to examine NAFO fishery system impacts and to explore the implications on the groundfish stocks due to removals by profitmotivated fishing fleets on the Grand Banks. The spreadsheet-based model traces the pattern of reported catches of key groundfish stocks on the Grand Banks since 1972 and examines the impact that declines in resource status have had on dependent Atlantic Canadian fishing communities' harvesting and processing activities. The paper also examines the economic viability of the domestic Canadian, and the Spanish and Portuguese distant water fishing fleets that participate in the 3LNO groundfishery on the Grand Banks NRA from 1998-2003. The objective of the scenario modeling exercise (Dembo, 1991) is to provide a quantitative framework for understanding the incentives of the system to the participants, and to evaluate the effectiveness of alternative management policies toward achieving its desired objectives.

\section{Model Components}

The Grand Banks fishery system model is described in three component parts: groundfish stocks, fleet segments, and Canadian communities. These components are described in more detail below.

\section{Groundfish Stocks}

A model is developed for describing each of the six key groundfish stocks of the Grand Banks in NAFO divisions 3LNO. These stocks and their respective management areas are: American plaice in 3LNO, Witch flounder in 3NO, Yellowtail flounder in $3 \mathrm{LNO}$, Cod in $3 \mathrm{NO}$, $2+3 \mathrm{KLMNO}$ Greenland halibut with specific interest in NAFO divisions 3LNO, and Redfish in 3LN and in 30.

The stocks' annual population profiles are based on independent age disaggregated estimates for stock size. 
These stocks are "NAFO stocks" whose habitat takes them to areas on the Grand Banks that are inside as well as outside the 200-mile EEZ of Canada on the Nose and Tail of the Grand Banks (Fig. 1). Areas outside 200 miles are fished by participating NAFO member countries in the NRA.

\section{Fleet Segments}

Catches of 3LNO groundfish stocks are typically taken by large, high seas groundfish trawlers (Gross Tonnage, GT $>1000$ t; vessel length, LOA $>50 \mathrm{~m}, \mathrm{EC}$, MS 2002, MS 2004; Varela-Lafuente et al., MS 2004) and since 1985 , factory freezer vessels that are high capacity vessels capable of processing fish at sea. Canada has primarily employed "wetfish" otter trawlers that require processing in shore-based plants. Portuguese fleets have also used high seas gillnets, and the Spanish have used pair trawls in the Grand Banks fisheries. Since before 1972 in the NRA, large trawlers from different NAFO member countries, e.g., Russia/USSR, France, Poland, South Korea, Canada, Spain and Portugal, have fished these groundfish stocks with varying intensity. Since the mid-1990s, Canada, Spain and Portugal have been most actively involved in catches of these groundfish stocks on the Nose and Tail of the Grand Banks, capturing about $75 \%$ of the total recorded annual catches of these stocks. The historical and current significant fleet segments that fish in 3LNO include:

Canada Maritimes and Newfoundland and Labrador fleets. The Canadian fleet is comprised of the Maritimes (Nova Scotia) fleet and the Newfoundland and Labrador fleet. The Newfoundland fleet is the dominant Canadian fleet on the Grand Banks. In some years since 1972, this fleet accounted for nearly all fish recorded captured in 3LNO by Canada from the mid-1970s to the early-1990s. Fleet size rose to over 70 vessels in the 1970 s but in recent years is now less than 20 active vessels. Catch shares dropped to less than $5 \%$ of total landings share by the mid-1990s then rising back to about $20 \%$ of total catches currently. Vessels' home ports and Grand Banks groundfish processing plants are typically located on the Avalon and Burin Peninsulas and along the South coast of Newfoundland. In the 1970s, integrated operations included Fisheries Products Limited of St. John's, the Lake Group also of St. John's (with original plant in Gaultois), and John Penny \& Sons (at Ramea on the south coast). Since the early 1980 s, following restructuring of the Canadian fishing sector (TFAF, 1982), Newfoundland vessels on the Grand Banks are operated by Fisheries Products International (FPI), the largest vertically integrated fishery operation in Atlantic Canada. The Newfoundland fleet was the primary exploiter of
American plaice, yellowtail flounder, cod and Greenland halibut up to the mid-1990s when NAFO imposed catch restrictions were invoked on American plaice and cod. After the mid-1990s, this fleet has concentrated on fishing for redfish, yellowtail flounder, and Greenland halibut. The Maritimes fleet is a minor fleet on the Grand Banks historically taking much less than $20 \%$ of the annual catch limit for any groundfish stock. Fleet size was as many as 10 trawlers in the mid- to late-1980s during a period of high intensity fishing on the Grand Banks, but now normally confined to one or two vessels fishing per year. This fleet accounts for less than $1 \%$ of total groundfish species catches on the Grand Banks in the early 2000's. Vessel home ports from this fleet are in Nova Scotia where vessels fish primarily on behalf of National Sea Products (now Highliner Fine Foods, Inc.) of Lunenburg, Nova Scotia.

Spanish fleet. Spain is a partner to the European Union (EU, formerly EEC); the EU is the recognized NAFO member. The Spanish fleet was historically active in the NRA on the Grand Banks especially for 3NO cod until 1995 when restrictive catch measures were imposed on this stock. The fleet recorded low catches of other groundfish species until the mid-1980s when the fleet became considerably more active on the Grand Banks especially for American plaice and redfish. Since the mid-1990s, the fleet fishes Greenland halibut and redfish with increasing catches of American plaice (although this stock remains under a directed catch moratorium). Fleet size in recent years is around 30 active vessels based on Canadian surveillance data. The active fleet fishes primarily on the Nose (3L) of the Grand Banks and spends about one-third of its remaining fishing effort in the southern NRA (3NO, the Tail of the Grand Banks). Spanish vessels make 1-3 trips per year of duration of approximately three months each trip. In 2005, fishing by the Spanish fleet was curtailed significantly.

Portuguese fleet. Portugal is also a partner to the EU. The Portuguese fleet has fished consistently in the NRA especially for cod until the mid-1990s when restrictive catch measures were applied. The fleet has made relatively low levels of capture for other groundfish stocks until the mid-1980s when fishing activities increased, especially on flounders (American plaice and Greenland halibut) whose nursery areas coincide with the Grand Banks NRA. Since the mid-1990s, catch shares of redfish and Greenland halibut have increased along with increases in American plaice (although this stock remains under a directed catch moratorium). The fleet of about 14 vessels fishes about two-thirds of the time on the Tail (3NO) of the Grand Banks and spends 
about one-third of its fishing effort in the northern NRA (3L, the Nose of the Grand Banks). Vessels fish all year long and make 1-3 trips per year of duration of nearly three months each trip.

For the Canadian fleet, processing activities tend to be land-based (shore-based processing plants). For the European Union fleets, processing activities may be either sea-based (e.g., Spanish factory trawlers on the NRA since 1985) or shore-based.

\section{Canadian Communities}

Information about actual landings and processed products by port community and stock are not readily available. Therefore, Canadian processing operations from the Grand Banks groundfishery are attributed to the designated Atlantic Canadian ports in the model according to assigned catch proportions based on: (1) the relative annual populations data by community (CC, 2005), and (2) fisheries workforce participation data by specific coastal communities where groundfish processing plants have operated (NL, 2005). Thus, for the Canadian fleets, local communities that are historically associated with the Grand Banks fisheries are identified. For this paper, designated communities (Table 1) represent a subset of all coastal communities that participated in the Grand Banks groundfisheries since 1972 through shore-based processing facilities.

Thus, the Grand Banks fishery system model examines components for: groundfish stocks, harvesting and processing by Canada and two EU fleet segments, and two groups of Nova Scotia and Newfoundland community processing centres.

\section{Methods and Data}

The Grand Banks fishery system descriptive model components provide the basis for developing the quantitative measures for the fishery system. These measures are defined in the functional modules designated as:

(i) assessment of the groundfish stocks,

(ii) input of the annual catch scenarios,

(iii) reporting of fleets' economic performance based on stock assessment and catch scenarios, and

(iv) Canadian communities' labour participation based on catches and fleet performance in the Grand Banks fisheries.

Fig. 2 presents a schematic of the main model inputs and outputs as well as illustrating how the model modules and components interact. These items are described in further detail below.
TABLE 1. Atlantic Canada communities by fleet segment.

\begin{tabular}{cll}
\hline \hline Number & $\begin{array}{c}\text { Canada: Maritime } \\
\text { communities }\end{array}$ & $\begin{array}{c}\text { Canada: Newfoundland and } \\
\text { Labrador communities }\end{array}$ \\
\hline 1 & Sydney & Trepassey \\
2 & Louisbourg & Burgeo/Ramea \\
3 & Halifax & Grand Bank \\
4 & Lunenburg & Marystown \\
5 & Canso & Burin \\
6 & & Harbour Breton \\
7 & & Catalina \\
8 & & Gaultois \\
9 & & Hermitage \\
10 & & St. John's \\
\hline
\end{tabular}

\section{Stock Assessment Module}

The six Grand Banks groundfish resources are described by the annual virtual population analysis (VPA) stock assessment estimates for each of the stocks from 1972 to the present. These estimates are documented in NAFO Scientific Council Reports (SCRs) and research documents typically using independent, area-aggregated, and age-disaggregated VPA methods. The stock assessment module proceeds by identifying the initial estimates of age distribution in numbers of fish for each of the six groundfish stocks denoted by $i$, where $i=1,2$, ..., 6. Population abundance, beginning in 1972, is denoted $N(i)_{a, 1972}$ for ages $a=1,2, \ldots, a(i)_{\max }$, and based on the historical results of the most recent stock assessment studies. The initial distribution numbers are combined with:

(i) average annual (constant) weights-at-age for each stock, denoted $w(i)_{a}$,

(ii) fishing technology information in the form of annual (constant) partial recruitment at age to the fishery from fishing practices, denoted $P R(i) a$, and

(iii) the schedule of annual recruiting year abundance, $R(i)_{t}=N(i)_{a r, t}$, where $t=1972, \ldots, 2005$, and $a r$ denotes the age of recruitment to the fishery.

The annual series of recruiting fish is taken from the NAFO SCRs data, as available. Finally, the annual schedule of the estimated continuous annual fishing mortalities for each stock, denoted by $F(i)_{t}, t=1972, \ldots$, 2005 (Fig. 2) is determined so that the calculated total annual catches at age, $\sum_{a} C(i)_{a, t}$ equal the recorded annual total catches by stock (Table 2 ). The model parameters are calculated according to the following Baranov catch equations: 
Abundance dynamics: $\quad N(i)_{a, t}=N(i)_{a-1, t-1} \exp \left(-M(i)-P R(i)_{a} F(i)_{t}\right)$
Start of Year Biomass: $\quad B(i)_{a, t}=w^{\prime}(i)_{a} N(i)_{a, t}$
Catch at age equation: $\quad C(i)_{a, t}=w(i)_{a} N(i)_{a, t}\left(1-\exp \left(-M(i)-P R(i)_{a} F(i)_{t}\right)\right) \frac{P R(i)_{a} F(i)_{t}}{M(i)+P R(i)_{a} F(i) t}$

where $M(i)$ is the age independent natural mortality and is set to the usual value of 0.2 per year, and $w^{\prime}(i)_{a}$ is the start of year weight at age estimated as $w^{\prime}(i)_{a}=\left(w(i)_{a}{ }^{+}\right.$ $\left.w(i)_{a}\right) / 2$.

For the cases of witch flounder and yellowtail flounder and redfish, for which no complete VPAs are available, age-disaggregated VPA proxy models were developed using available estimates on total abundance (yellowtail and redfish) or abundance at age (witch flounder), partial recruitment at age from surveys (witch flounder) or from relative lengths in stock surveys and age-length frequency distributions (yellowtail and redfish), and weight at age (witch flounder) or age-weight functions (yellowtail and redfish). Abundance and biomass at age estimates for these stocks were calibrated to the total annual catches and fishing mortality data reported over the study period. It is recognized that age-based methods applied to these non-VPA stocks are problematic. Emphasis for these stocks is on the trends in the total stock estimates arising from the proxy VPA model rather than the details of the age-based descriptions.

Catches at age, $C(i)_{a, t}$, are used as input to annual fisheries production analyses to determine product revenues to the fleets that are a function of catch size (proxy by age). Model catches are calibrated to actual annual catch totals by stock, but not to actual catches at age, nor to the annualized VPA catch at age estimates (that include year-over-year weight at age differences). The model-based catches provide the same trend of stock dynamics over the study period based on the VPA estimates from the most recent assessments for each stock. This approach permits the exploration of hypothetical fishing intensities based on changes to annual fishing mortalities, $F(i)_{t}$, and annual catches, $\sum_{a} C(i)_{a, t}$, while

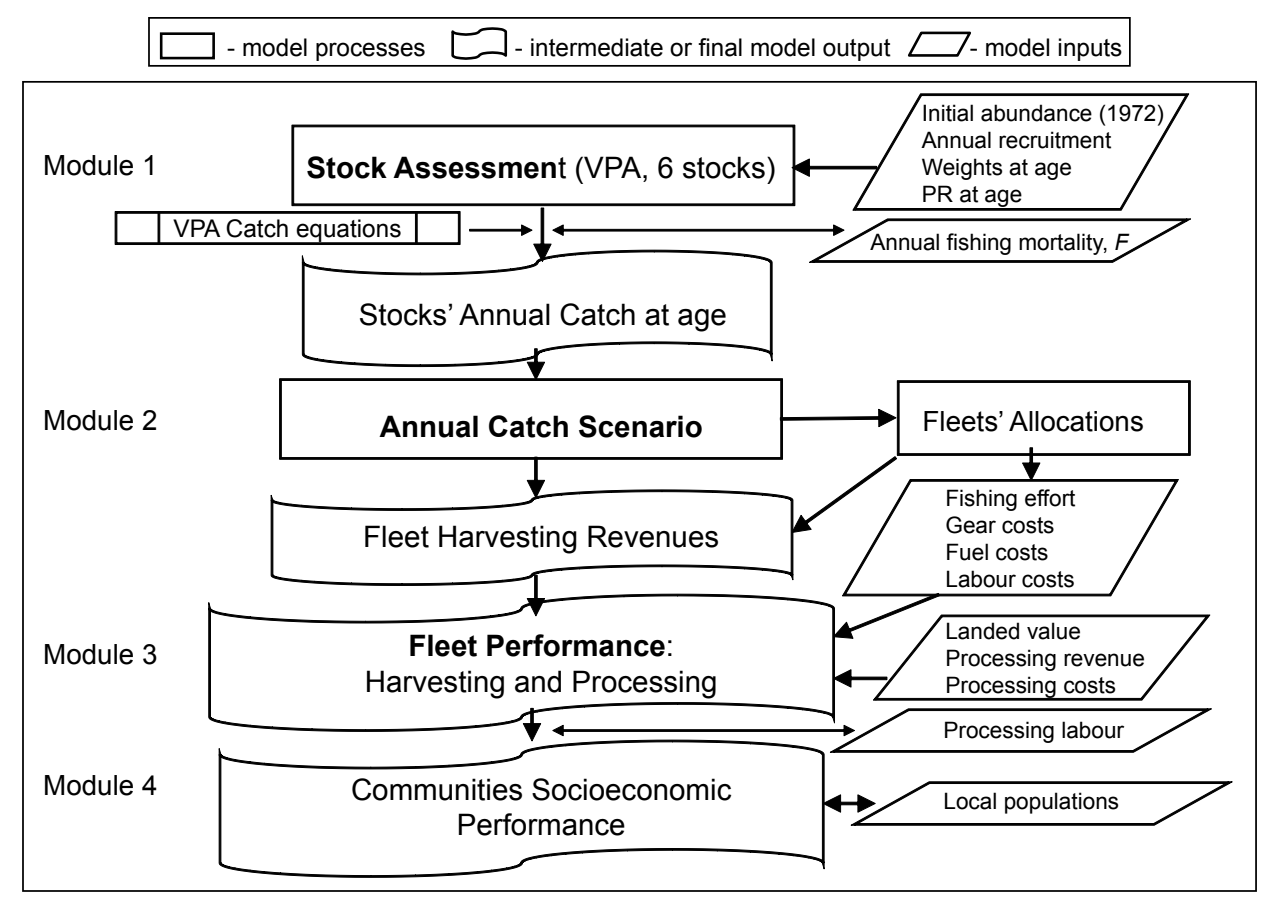

Fig. 2. Grand Banks Fishery Model Schematic. 
TABLE 2. Stock assessment data for 3LNO American plaice for start of study, 1972 (Morgan et al., MS 2003; Dwyer and Morgan, MS 2004; González Troncoso et al., MS 2004).

\begin{tabular}{cccccc}
\hline \hline \multirow{2}{*}{$\begin{array}{c}\text { Age class } \\
\text { (years) }\end{array}$} & \multicolumn{2}{c}{ Numbers } & $\begin{array}{c}\text { Partial } \\
\text { Recruitment } \\
\left(P R_{a}\right)\end{array}$ & $\begin{array}{c}\text { Mean Weight } \\
\left(w_{a}, \mathrm{~kg}\right)\end{array}$ & $\begin{array}{c}\text { Population } \\
\text { Biomass } \\
\left(B_{a, 1972}, \mathrm{t}^{1}\right)\end{array}$ \\
\hline 1 & 21.8 & 543725 & 0 & 0.00 & 54 \\
2 & 17.8 & 445164 & 0 & 0.02 & 8903 \\
3 & 14.6 & 364470 & 0 & 0.09 & 32802 \\
4 & 11.9 & 298403 & 0 & 0.15 & 44760 \\
5 & 9.8 & 244311 & 0.05 & 0.17 & 41533 \\
6 & 6.7 & 168180 & 0.20 & 0.23 & 38681 \\
7 & 4.4 & 109299 & 0.40 & 0.31 & 33883 \\
8 & 3.6 & 89191 & 0.70 & 0.40 & 35676 \\
9 & 2.7 & 66971 & 1.00 & 0.50 & 33486 \\
10 & 2.2 & 55225 & 1.00 & 0.60 & 33135 \\
11 & 1.6 & 40387 & 1.00 & 0.75 & 30291 \\
12 & 1.2 & 30721 & 1.00 & 0.93 & 28570 \\
13 & 0.6 & 15784 & 1.00 & 1.15 & 18152 \\
14 & 0.4 & 10770 & 1.00 & 1.45 & 15617 \\
15 & 0.7 & 17397 & 1.00 & 1.84 & 32010 \\
\hline Total & 100.0 & 2500000 & & & 427555 \\
\hline${ }^{1}$ One ton (t) equals $1000 \mathrm{~kg}$. & & & &
\end{tabular}

maintaining the estimated VPA catch at age and population impacts at age structures. Table 2 presents the initial data for calculating age disaggregated stock abundance, mean weights at age, partial recruitment at age values, and initial stock biomass at age for the 3LNO American plaice stock $\left(N(1)_{a, 1972}, w(1)_{a}, P R(1)_{a}, B(1)_{a, 1972}\right)$ determined from the NAFO SCR reports on this stock by Morgan et al. (MS 2003), Dwyer and Morgan (MS 2004), and González Troncoso et al. (MS 2004).

The schedule of recorded annual total (all countries) catches of the groundfish stocks in the NRA are provided in the NAFO fishery statistics by stock. Given these catch schedules, the stock assessment modules calculates the equivalent rates of fishing mortality, $F(i)$, for each stock, $i=1,2, \ldots, 6$, over the study period, $t=1972,1973, \ldots$, 2005. These derived fishing mortality schedules assume year-over-year partial recruitment by age vectors as used in the stock VPA analyses. Fig. 3 presents the graphical schedule of fully recruited fishing mortalities estimates for the six groundfish stocks in the Grand Banks fishery system model.

The schedule of annual stock recruitment is available for Grand Banks groundfish stocks as part of the vir- tual population assessment models. However, for some stocks, notably, witch flounder and yellowtail flounder, and redfish, recruitment schedules were unavailable since alternative procedures were used to estimate abundance of these stocks, e.g., surplus production model in the case of yellowtail flounder (Brodie et al. MS 2004), standardized catch rates in the case of redfish (Power, MS 2003a, 2003b). Data on yellowtail flounder were obtained from descriptive reports on the stock (e.g., data on weight at age from length at age provided in Canada 1994) to reconstruct the time series of yellowtail abundance over the study period. Results for these stocks were calibrated to the NAFO stock abundance estimates by adjusting the schedule of annual stock recruitment. For redfish, start of year biomass levels were based on survey biomass estimates provided for NAFO Divisions $3 \mathrm{LN}$ and $3 \mathrm{O}$ separately. The stock recruitment schedule and fishing mortalities were set to replicate recorded total catch values for redfish stocks in $3 \mathrm{LN}$ and $3 \mathrm{O}$.

\section{Annual Catch Scenario Module}

Total annual stock catches are determined from the online STATLANT 21A Fish Statistics database, using the Fish Stats Plus, version 2.3 software, that records national catches and landings provided to the NAFO 


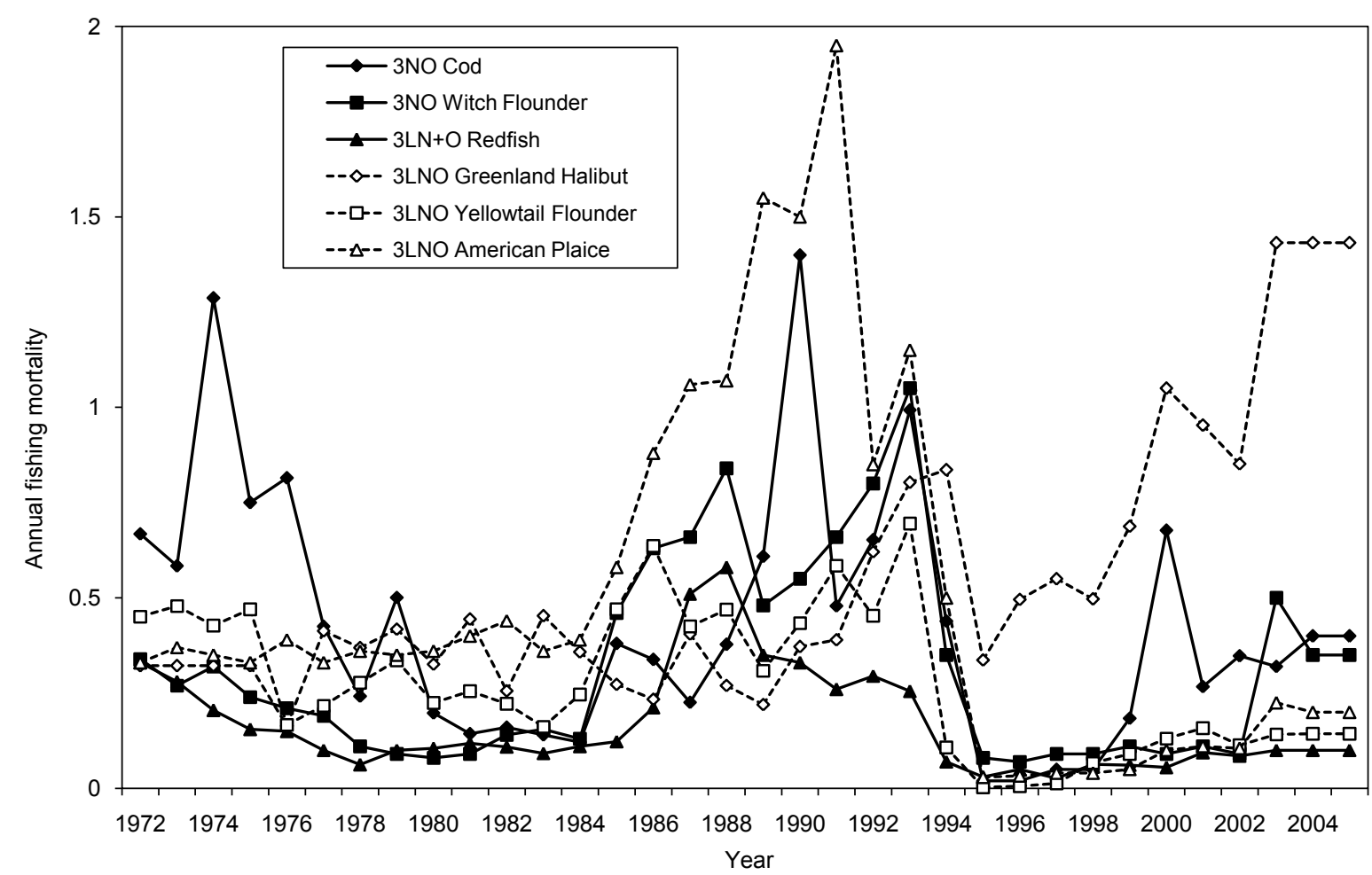

Fig. 3. Estimated annual fishing mortalities $(F)$ for six NAFO assessed stocks (Brodie et al., MS 2004; Darby et al., MS 2003; Dwyer and Morgan, MS 2004; Healey et al., MS 2003; Morgan et al., MS 2003; Parsons, MS 2004; Power, MS 2003a, MS 2003b). Fishing mortalities for 2004 and 2005 are assigned values equal to the last known year of estimated data.

Secretariat by NAFO member countries, by NAFO division, and by species (http://www.nafo.int/fisheries/stats/ 21stats.html).

Revisions to the Fisheries Statistics data for annual landings catch statistics are recorded in the NAFO SCRs and assessment research documents for each stock and by fleet segment. These revisions take into account atsea boarding and other (e.g., aerial surveillance) survey inspection data, including data from the International Observer Program (IOP), that are not necessarily recorded by the NAFO member fishing nation provided catch statistics. These revised catches are denoted as the "Status quo catch" scenario.

There is uncertainty associated with actual catches and annualized fishing mortalities on some Grand Banks stocks, in spite of "no directed fishing" restrictions. By implication, recorded catches underestimate actual stock removals. These differences are expressed between country reported catches, as provided in the NAFO STATLANT 21A Fish Statistics database, and revised catches by country that appear in the NAFO SCR scientific stock assessment analyses. For example, the data recorded in Table 2 of Morgan et al. (2003) for the stock assessment of 3LNO American plaice for 1999-2002, provide a breakdown of "other" catches by country that are significantly different (up to nearly four times) that attributed to Spain and Portugal compared with the national data reported in the NAFO STATLANT 21A database.

In order to explore the affects of larger than reported removals, alternative series of annual catches have been hypothesized for the fishing activities of the Spanish and Portuguese fleets. Increased removals scenarios are based on:

(i) the litany of qualitative reports noted continually in the NAFO STACFIS reports on meetings (NAFO, 1980-2002) referring to "increasing catches since despite no directed fishing restrictions", and "substantial, unquantified catches of young, immature fish",

(ii) elevated fishing activities and DFO reported vessel activity in the NRA since 1997, and

(iii) the SCR revisions to reported catch values.

Alternative catch schedules are presented that assign higher annual groundfish catches to the Spanish and Portuguese fleets operating in the Grand Banks NRA from 1998. The catch schedule scenarios for the six groundfish stocks analysed in the model for the recent period 
TABLE 3. Status quo scenario annual catches (t) for 1998-2003 (Brodie et al., MS 2004; Darby et al., MS 2003; Dwyer and Morgan, MS 2004; Healey et al., MS 2003; Morgan et al., MS 2003; Parsons, MS 2004; Power, MS 2003a, MS 2003b).

\begin{tabular}{|c|c|c|c|c|c|c|c|}
\hline \multirow[b]{2}{*}{ Species } & \multirow[b]{2}{*}{ Country } & \multicolumn{6}{|c|}{ Year } \\
\hline & & 1998 & 1999 & 2000 & 2001 & 2002 & 2003 \\
\hline \multirow[t]{3}{*}{$3 \mathrm{NO} \mathrm{Cod}$} & Canada & 286 & 396 & 568 & 207 & 560 & 444 \\
\hline & Spain & 95 & 3 & 201 & 90 & 58 & 0 \\
\hline & Portugal & 56 & 322 & 503 & 405 & 584 & 577 \\
\hline \multirow[t]{3}{*}{ 3NO Witch flounder } & Canada & 2 & 6 & 12 & 13 & 26 & 62 \\
\hline & Spain & 411 & 362 & 334 & 457 & 120 & 635 \\
\hline & Portugal & 187 & 228 & 94 & 146 & 97 & 676 \\
\hline \multirow[t]{3}{*}{$3 \mathrm{LN}+\mathrm{O}$ Redfish } & Canada & 8977 & 2344 & 2257 & 4915 & 3048 & - \\
\hline & Spain & 2471 & 5065 & 3945 & 2518 & 882 & 1804 \\
\hline & Portugal & 2761 & 6432 & 5107 & 3928 & 5008 & 6691 \\
\hline \multirow[t]{3}{*}{ 3LNO Greenland Halibut } & Canada & 737 & 812 & 444 & 3024 & - & - \\
\hline & Spain & 5175 & 5831 & 7201 & 9151 & 10271 & 9602 \\
\hline & Portugal & 2550 & 3394 & 4231 & 3803 & 3738 & 3742 \\
\hline \multirow[t]{3}{*}{ 3LNO Yellowtail flounder } & Canada & 3739 & 5746 & 9463 & 12238 & 9959 & - \\
\hline & Spain & 562 & 752 & 1114 & 1391 & 161 & 381 \\
\hline & Portugal & 85 & 300 & 247 & 320 & 461 & 491 \\
\hline \multirow[t]{3}{*}{ 3LNO American Plaice } & Canada & 227 & 323 & 623 & 1617 & 1375 & 1607 \\
\hline & Spain & 993 & 1243 & 1271 & 659 & 705 & 850 \\
\hline & Portugal & 314 & 700 & 373 & 471 & 559 & 873 \\
\hline \multirow[t]{4}{*}{ All Stock Totals } & Canada & 13968 & 9627 & 13367 & 22014 & 14968 & 2113 \\
\hline & Spain & 9707 & 13256 & 14067 & 14266 & 12196 & 13272 \\
\hline & Portugal & 5953 & 11376 & 10554 & 9074 & 10446 & 13050 \\
\hline & Total EU & 15660 & 24632 & 24621 & 23339 & 22642 & 26322 \\
\hline
\end{tabular}

1998-2003 (that marks the return of fishing activity to the Grand Banks by all fleets following the 1995 NAFO directed catch moratoria on American plaice, witch flounder, and cod) are defined as follows:

Status quo - benchmark catches as reported in the NAFO SCR documents for the Grand Banks groundfish stock assessments (Table 3);

Increased EU catches - this schedule doubles the catch rates reported annually by the EU fleets. This scenario effectively doubles annual catches reported as Status quo catches (catch scenario I) for Spain and Portugal by species catches;

Increased EU small fish catches - this catch schedule uses the same increases as in catch scenario II above (doubling) but applied through adjustments in the partial recruitment of small fish (juveniles).

Table 3 presents the 1998-2003 annual catch schedule for the Status quo catch scenario for the Canadian (total) and the EU fleets Spain and Portugal. All catches are in metric tonnes $(\mathrm{t})$. For 2003, Table 3 reports that total EU catches were $26322 \mathrm{t}$ in $3 \mathrm{LNO}$ on the six groundfish stocks of this study divided roughly equally (approximately $13000 \mathrm{t}$ each) between the Spanish and Portuguese fleets.

Total catches of all stocks in the Northwest Atlantic NAFO NRA in 2003 as reported by the Portuguese are $19700 \mathrm{t}$ (EC, MS 2004). Spanish reported catches in the whole Northwest Atlantic NAFO NRA in 2003 are 25484 t (Varela-Lafuente et al., MS 2004). These catches are higher than those recorded in Table 3 (13 $050 \mathrm{t}$ and $13272 \mathrm{t}$, respectively, for Portugal and Spain) since they also include removals of cod and redfish from the Flemish Cap (NAFO Division 3M), and removals of skates and grenadiers that are not taken into account in this study.

\section{Fleet Performance Module}

Each of the fleet segments is modeled on the basis of the annual economic performance of an "average" vessel 
in their respective fleets. As well, the annual economic performance for the active fleet as a whole is estimated with particular emphasis on the recent period from 1998-2003.

Fleet economic performance is estimated from annual total catches by species as allocated to each fleet according to the Status quo catch scenario. In each year, the fleet segments of interest are apportioned their total annual catch by species. These annual catches attribute annual raw materials (landed value) to the respective fleets for the purposes of recording revenue generation and economic performance of the harvesting operations. Processing revenues are attributed according to the assignment of harvested catches by age groups to fish product groups. Age groups are aggregated and denoted as: small fish, juvenile fish, adult fish, and large fish. Age groups definitions vary for each of the stocks. The fish catch by age groups are then assigned to final processed products (DFO Economics and Statistics, unpublished data; Seafoodexport, 2005) denoted as follows:

Blocks - head off, and gutted fish parts including "offcuts" and trimmings minced and frozen into blocks and formed into sticks for further processing;

Fillets - prepared after gutting and washing, fish may be iced and kept in chilled storage at sea ("wetfish") to preserve the quality of the product; during onshore or at sea processing, fish are washed, headed, and machine filleted; fillets are trimmed and graded for size, then packed before quick freezing;

Whole and Dressed - whole ("head on") fish production applies mainly to small fish where fish are washed, graded for size, and quick frozen at sea; dressed ("headed and gutted" or $\mathrm{H} / \mathrm{G}$ ) fish for whole freezing (especially redfish and Greenland halibut) are washed size graded and quick frozen;

Other products - includes salt fish products wetfish processed by splitting or filleting (especially cod) that are then trimmed and placed in brine in large tubs where they are "cured", fish for meal (from skin, skeleton, head parts and muscle remnants).

The relative fishing effort of the fleet segments are calculated for comparative proposes on the basis of the schedule of fleets' annual catches by stock. Annual catches by the fleets are calculated by assigning the appropriate catch proportion to the fleets of the recorded total annual catch by all NAFO member countries fishing in the NRA of the Grand Banks.

Fleet economic performance is determined for the integrated analysis of the harvesting and processing op- erations combined. Fleet economic performance for harvesting, processing, and the integrated views of the fleets is measured using standard business pro forma reports including annual profit statement; annual calculation of cash; efficiency ratios reports; balance sheet (net worth) report; report of financial ratios, and capital cost allowance reports.

Revenues. Revenues from fishing are a function of the catch by stock, the distribution of catches by age, and the transformation of the raw catches into final processed products. Catch at age statistics for each stock are attributed to each fleet according to the stock population model estimates, the annual partial recruitment data that reflects technology adjustment over time, and the fleet's catch allocation (as assigned above based on country catch statistics). Revenues are calculated from fleet catches based on the proportional assignment of catch at age for each groundfish stock to the major fish product groups, namely, blocks, fillets, whole/dressed, and other products. Prices $(\$ / \mathrm{kg})$ are assigned to the products by species over each year of the study period.

Based on Canadian export data statistics, the approximate disposition of Grand Banks annual catches of all stocks to the major product markets in recent years are: $10 \%$ to blocks, $70 \%$ to fillets, $10 \%$ to whole/dressed, and $10 \%$ to other products, e.g., salted, meal, fish oil. Raw material disposition to products varies by size category of the catch, e.g., among small fish, only about $80 \%$ are utilized. The remaining $20 \%$ of small fish are lost due to discarding at sea or as waste in processing operations (MoF, 2005.) Similarly, data on product disposition are based on Canadian (Newfoundland) annual exports over the 1998-2003 period (DFO, 2005a). These Canadianbased data are also pro-rated to each of the EU fleets.

Raw material distribution of fish catches to final products is modeled as being dependent on the stock, and on the changes in the market for fish products over time. For example, the disposition of cod in the 1970s and 1980s into fish blocks and salted ("other") product forms has shifted from as much as $50 \%$ to $10 \%$ since 1991 into higher valued fillets that now constitute $75 \%$ of the cod catch from $30 \%$ previous to 1991 . The markets for the flatfishes (American plaice, yellowtail and witch flounder, and Greenland halibut) have been more exclusively in fillets with little raw material going to blocks and other products since the 1990s.

Table 4 shows the annual prices per kilogram of processed product assumed for the four major products by stock of groundfish for the period 1998-2003. These data are derived from Canadian (Newfoundland) annual 
TABLE 4. Final processed product prices for 1998-2003 (\$ per kg produced) by major market for six NAFO stocks (DFO, 2005b).

\begin{tabular}{|c|c|c|c|c|c|c|}
\hline Market & 1998 & 1999 & 2000 & 2001 & 2002 & 2003 \\
\hline \multicolumn{7}{|c|}{ 3LNO American Plaice } \\
\hline Blocks & 2.00 & 2.00 & 2.00 & 2.00 & 2.00 & 2.00 \\
\hline Fillets & 9.49 & 9.11 & 8.73 & 8.35 & 7.97 & 7.59 \\
\hline Whole/Dressed & 3.23 & 3.03 & 2.83 & 2.63 & 2.43 & 2.23 \\
\hline Other & 2.00 & 2.00 & 2.00 & 2.00 & 2.00 & 2.00 \\
\hline \multicolumn{7}{|c|}{ 3NO Witch Flounder } \\
\hline Blocks & 2.00 & 2.00 & 2.00 & 2.00 & 2.00 & 2.00 \\
\hline Fillets & 9.49 & 9.11 & 8.73 & 8.35 & 7.97 & 7.59 \\
\hline Whole/Dressed & 3.23 & 3.03 & 2.83 & 2.63 & 2.43 & 2.23 \\
\hline Other & 2.00 & 2.00 & 2.00 & 2.00 & 2.00 & 2.00 \\
\hline \multicolumn{7}{|c|}{ 3LNO Yellowtail Flounder } \\
\hline Blocks & 2.00 & 2.00 & 2.00 & 2.00 & 2.00 & 2.00 \\
\hline Fillets & 9.49 & 9.11 & 8.73 & 8.35 & 7.97 & 7.59 \\
\hline Whole/Dressed & 3.23 & 3.03 & 2.83 & 2.63 & 2.43 & 2.23 \\
\hline Other & 2.00 & 2.00 & 2.00 & 2.00 & 2.00 & 2.00 \\
\hline \multicolumn{7}{|l|}{$3 \mathrm{NO}$ Cod } \\
\hline Blocks & 4.50 & 4.00 & 3.50 & 3.00 & 2.50 & 2.00 \\
\hline Fillets & 8.25 & 8.25 & 8.25 & 8.25 & 8.25 & 8.25 \\
\hline Whole/Dressed & 3.10 & 3.90 & 4.70 & 5.50 & 6.30 & 7.10 \\
\hline Other & 6.48 & 6.81 & 7.14 & 7.47 & 7.80 & 8.13 \\
\hline \multicolumn{7}{|c|}{ 3LNO Greenland Halibut } \\
\hline Blocks & 3.38 & 3.44 & 3.50 & 3.56 & 3.62 & 3.68 \\
\hline Fillets & 8.02 & 7.42 & 6.82 & 6.22 & 5.62 & 5.02 \\
\hline Whole/Dressed & 4.47 & 4.51 & 4.55 & 4.59 & 4.63 & 4.67 \\
\hline Other & 2.00 & 2.00 & 2.00 & 2.00 & 2.00 & 2.00 \\
\hline \multicolumn{7}{|l|}{$3 \mathrm{LN}+\mathrm{O}$ Redfish } \\
\hline Blocks & 2.00 & 2.00 & 2.00 & 2.00 & 2.00 & 2.00 \\
\hline Fillets & 8.25 & 8.25 & 8.25 & 8.25 & 8.25 & 8.25 \\
\hline Whole/Dressed & 3.23 & 3.03 & 2.83 & 2.63 & 2.43 & 2.23 \\
\hline Other & 2.00 & 2.00 & 2.00 & 2.00 & 2.00 & 2.00 \\
\hline
\end{tabular}

exports for 1998-2003 and are likewise assumed to apply to each of the EU fleets' catches (DFO, 2005b). Product prices information were made available for cod, Greenland halibut, and "flounders". As above, prices data for the "flounders" were assumed to apply to each of the stocks of American plaice, yellowtail flounder, and witch flounder. In the absence of prices data for redfish, redfish fillets prices were set equal to the cod prices dataset over the years 1998-2003.

Dynamic price changes for the stocks in Table 4 were determined from the linear trend of actual prices data available for cod, Greenland halibut, and flounders by major market group. This analysis captured the fall in actual (nominal) prices for cod blocks of 50 cents (CDN) yearly from 1998-2003 and the rise in cod whole/dressed product by 80 cents per $\mathrm{kg}$ per year on average. Similarly, Greenland halibut prices for fillets decline over this period by 60 cents per $\mathrm{kg}$ per year while whole/dressed Greenland halibut prices increase by 4 cents per kg annually. Finally, actual prices for flounders fell by 38 cents and 20 cents per $\mathrm{kg}$ per year for fillets and whole/dressed product, respectively. Dynamic price changes form the basis for the stock-product prices of Table 4. 
Costs. Operating costs are a function of harvesting and processing activities. Harvesting costs include the annual costs of operating vessels, including fuel, provisions, labour (crew and owners' share), vessel maintenance and repairs, fixed costs (insurance, licensing) and the costs of capital (e.g., depreciation, interest expense, etc.). Processing costs include packaging, labour, and capital costs. Average vessel operating costs of harvesting are determined from information provided on trawler vessel performance (e.g., EC, MS 2002, MS 2004) as well as from unpublished DFO and Canadian trawler sources. Operating cost data and revenues attributed to markets from catches provide economic performance information for the fleets.

The costs of harvesting and processing are specific to each of the fleet segments. Variable costs of harvesting operations are a function of the annual catches with major items being the costs of fuel and harvesting and processing labour. These items include the rate of crew and captain labour as a function of the landed value of the catch; average annual expense items per vessel in the fleet including repairs, licensing, insurance, miscellaneous expenses; expense rates for the cost of debt, income tax rate, investment rate on after-tax cash; costs of fishing effort per standard day fishing; and by vessel accounts for mortgages and other debts, asset accounts, and capital accounts.

Operating cost data for the EU fleets are estimated from data for the Portuguese fleets operating in the NAFO NRA (EC, MS 2002, MS 2004). Estimates for the Portuguese fleet are applied to the Spanish fleet in the absence of data for this fleet segment. All fleets' revenue and cost data are recorded in nominal Canadian dollars.

Spanish Fleet Fishing Effort. The following information and assumptions on the Spanish fishing operations costs are based on DFO unpublished documents. Vessels in the Spanish fleet are assumed to spend twothirds of their fishing effort in NAFO Division 3L in the area of the Nose of the Grand Banks, and the remainder of time fishing roughly equally between $3 \mathrm{~N}$ and $3 \mathrm{O}$ on the Tail of the Grand Banks. On average, Spanish vessels are assumed to spend 270 total days fishing per vessel per year or, equivalently, an average of 45 days per year directing on each of the six Grand Banks groundfish stocks. This equates to an average of 30 days per species in $3 \mathrm{~L}$ and 7.5 days per species in $3 \mathrm{~N}$ and $3 \mathrm{O}$. Average trip lengths for vessels in the Spanish fleet are approximately 110 days per round trip (including approximately 14 days sailing to and from the fishing grounds) with an average of 2.5 trips per vessel per year at full capacity.
Under the Status quo catch scenario, effort per standard day fishing is assumed to yield approximately $600 \mathrm{t}$ per 110 day fishing trip, or, equivalently, approximately $5.4 \mathrm{t}$ per day of all stocks fished by the Spanish fleet in the NRA. These catches include stocks on the Flemish Cap (NAFO Division 3M), and other unregulated stocks 3LNO (e.g., skate, grenadiers, and white hake) of Grand Banks groundfish not included in this study. For the Spanish fleet, the fishery on the six groundfish stocks in the Grand Banks fishery, the Status quo catch scenario assumes a rate of fishing of approximately $275 \mathrm{t}$ per trip (of the $600 \mathrm{t} /$ trip assumed actual capacity, or approximately one-half of total trip catches at $2.5 \mathrm{t} /$ day for Spanish trips of 110 days/trip). This assumption re the Spanish fleet is based on 26 fully active vessels for 2003. From these assumptions, the estimated standard effort days of 26 vessels at 270 days per vessel per year amount to 7020 standard effort days for 2003. This estimate approximates the independent Spanish estimate for 2003 fishing effort in the NRA (6 800 days) from DFO personnel communications.

Portuguese Fleet Fishing Effort. The following information and assumptions on the Portuguese fishing operations costs are based on DFO unpublished documents. The Portuguese fleet is assumed to apportion its fishing effort in the NRA equally among NAFO Divisions $3 \mathrm{~L}$ ( $1 / 3$ of effort on the Nose of the Grand Banks), and $3 \mathrm{~N}$ and $3 \mathrm{O}(1 / 3$ each of fishing effort on the Tail of the Grand Banks). On average, Portuguese vessels are assumed to spend 42 days per year per stock in the NRA (i.e., 14 days in each of $3 \mathrm{~L}, 3 \mathrm{~N}$, and 3O). This amounts to 252 days per Portuguese vessel per year (or, 42 days per vessel per species times the six species of this study). Portuguese vessel trips are assumed to be on average 100 days per round trip (including approximately 14 days sailing to and from the fishing grounds) with an average 2.5 trips per vessel per year.

As in the case of the Spanish fleet, under the Status quo catch scenario, effort per standard day fishing by the Portuguese fleet is assumed to yield approximately $600 \mathrm{t}$ per 110 day fishing trip, or, equivalently, approximately $6 \mathrm{t}$ per day of all stocks fished by the Portuguese fleet in the NRA. As before, these catches also include nonGrand Banks stocks such as stocks on the Flemish Cap (NAFO Division 3M), and other previously unregulated stocks in 3LNO (e.g., grenadiers, skate, and white hake; skate and white hake were regulated as of 2005). For the six groundfish stocks in the Grand Banks fishery in this study, the Status quo catch scenario assumes a Portuguese fleet rate of fishing of approximately $400 \mathrm{t}$ per trip of the $600 \mathrm{t}$ actual capacity (or two-thirds of total trip 
catches at $4 \mathrm{t}$ /day for Portuguese trips of 100 days/trip). This assumption for the Portuguese fleet is based on 14 active vessels in the NRA for 2003. From these assumptions, the estimated standard effort days of 14 vessels at 252 days per vessel per year amount to 3528 standard effort days for 2003 (including fishing and sailing to and from port to the fishing grounds.) This estimate approximates the independent 2003 Portuguese fishing effort data in the NRA under the Status quo catch scenario from Canadian DFO unpublished documents (2 600 days) as well as from the EC (MS 2002, MS 2004) (3 600 days).

Fuel Costs. Fuel is the major operating cost for the Grand Banks fleet operations by the EU fleets. It is assumed that fuel costs are $\$ 3800^{1}$ per day fishing (DFO, unpublished data). Thus, for the Spanish and Portuguese fleets fishing at 110 days and 100 days per trip, respectively, the assumed operating costs for fuel are $\$ 418000$ and $\$ 380000$ per trip (compared with other estimates of approximately US $\$ 560000$ for 160 day trips assumed for both EU fleets). Thus, for fleet sizes estimated at 26 and 14 fully active vessels in the Spanish and Portuguese fleets, respectively, the annual fleet fuel costs (assuming 2.5 trips per year per EU vessel) used in the model are estimated at approximately $\$ 30$ million and \$13 million for the Spanish and Portuguese fleets. The EC (MS 2004) estimates the fuel costs for the Portuguese fleet at the comparable value of $€ 7.6$ million for 2003 (approximately $\$ 12$ million).

Labour Costs. Crew labour harvesting costs are computed for the EU fleets assuming average vessel crew size of 35 per Spanish vessel and 25 per Portuguese vessel (2003 fleet sizes as per the EC, MS 2004). Vessel crew harvesting labour is calculated as a percentage of the landed value of the catch. Percentages for the Spanish and Portuguese fleets are $30 \%$ and $35 \%$ of landed value, respectively (as estimated from the EC, MS 2004; DFO, unpublished data). Landed value estimates for the EU fleets are based on annual quantities and total values calculated as values per $\mathrm{kg}$ of catch by NAFO stocks from Newfoundland exports statistics for 1998-2003 (DFO, 2005b). Similarly, officers' or captains' shares are estimated at $20 \%$ of annual landed values for both EU fleets. Crew provisions for EU vessels are costed in the model at $\$ 10.00$ per crew per day (compared with DFO estimates of US $\$ 7.25$ per EU crew members daily). This equates to $\$ 250$ per day for Spanish vessels and $\$ 350$ per day for Portuguese vessels on average.

Gear Operating Costs. Repair and maintenance and gear operating costs for the EU vessels are estimated in the model at $\$ 300000$ per vessel annually for repair and maintenance including annual refit (based on approximately US \$1 500 per day fishing per vessel for vessel repair and maintenance and US $\$ 100000$ per vessel for annual refit), and US \$200 000 per vessel for gear and electronics (based on approximately $\$ 725$ per day fishing per vessel).

The annual revenues and costs data assumed for the EU fleet operations determine the net operating income of these fleets under given catch assumptions by these fleets. Net operating income is a key model measure for determining fleet economic viability.

\section{Communities Socioeconomic Performance Module}

The Canadian fleets' annual harvests of Grand Banks groundfish imply related processing sector activities in coastal communities. Costs attributed to processing are separated from the identified costs of harvesting by vessels. The socioeconomic impacts on the Canadian Maritimes and Newfoundland communities over the planning period are measured by attributing total fleet catches and associated processing activities over all species fished on the Grand Banks to labour participation of the selected communities.

Historical annual labour participation estimates are established based on assumptions about the equivalent person-years (PYs) estimated to produce one metric tonne of harvesting and processing of the Grand Banks groundfish species. The schedules of labour participation in the Grand Banks fishery by person-years and by labour earnings are determined over the study period from 1972. Community labour estimates computed as a function of attributed catches are compared to available community census information on community populations over time, available workforce, labour participation, and labour earnings from the Canada Census data for the years 1971, 1976, 1981, 1986, 1991, 1996, and 2001 (CC, 2005) as well as from communities reports (NL, 2005).

The historical analysis of the labour impact on Canadian communities that participated in the Grand Banks fishery over the study period proceeds from a review of the demographics of the communities from 1972 to the present. Population estimates for the Maritimes and Newfoundland communities were determined from the Canada Census reports between 1971-2001. The breakdown of the populations into ages $15+$ constitute the eligible workforce for fish harvesting and processing in these dependent communities. Workforce availability rates for the fisheries were based on eligible workforce estimates for the communities. For communities, (cities of Halifax, Sydney, and St. John's excepted) available

\footnotetext{
All dollars are Canadian dollars unless otherwise specified. Over the last 10 years, the average (and range) for one Canadian dollar has been US $\$ 0.73(0.62-1.03)$ and Euro $€ 0.67(0.57-0.78)$.
} 
fisheries workforce proportions vary between $7 \%$ and $21 \%$ of the total communities' populations (NL, 2005).

\section{Analyses and Results}

The analysis of EU trawler performance measures and Canadian community fishery employment, proceeds by using the model to calculate impacts under selected scenarios for the required data definitions. Impacts are considered to be relative to the dataset and not absolute in value - rather, they represent "best estimates" for the data available. Under the case of considerable data uncertainty, the model provides the opportunity to explore a suite of alternative data definitions and problem scenarios as experiments for determining the historical impacts on Canadian communities of interest, and for estimating groundfish fleet viability. This section describes the analyses results by modules for stock assessment, annual catch scenarios, fleet economic performance, and community labour participation.

\section{Stock Assessment Module Results}

Key measures of the overall performance of the stock abundance module include the annual stock abundance (numbers) and stock biomass for the six stocks in the Grand Banks groundfishery system model. The annual exploitable stock biomass over all stocks, 1972-2005, Fig. 4, corresponds to the stock estimates under the assumption of the annual Status Quo catch scenario (e.g., see Table 3 for status quo catches from 1998-2003).

The relatively higher overall stock status evident for the mid-1970s to the mid-1980s decade is followed after the mid-1980s by high intensity exploitation on all groundfish stocks and increases in stock catches until the mid-1990s. By 1995, the resulting NAFO catch restrictions on some stocks are marked by sharp declines in fishing mortalities and catches on all stocks (see also Fig. 3). Over all stocks, these restrictions have meant lower fishing mortalities and a slight increase in overall stock biomass to the start of the new millenium. Since 1995, aggregate Grand Banks groundfish biomass has notably increased to a peak in 2000 before falling off again to 2003 to overall levels similar to the overall period low total of the 1995 period.

Model results are identified on a stock by stock basis. For example, stock assessments for American plaice are taken from the recent SCRs by Morgan et al. (MS 2003), Dwyer and Morgan (MS 2004), and González Troncoso et al. (MS 2004). Annual stock estimates and total catch at age information were determined from data

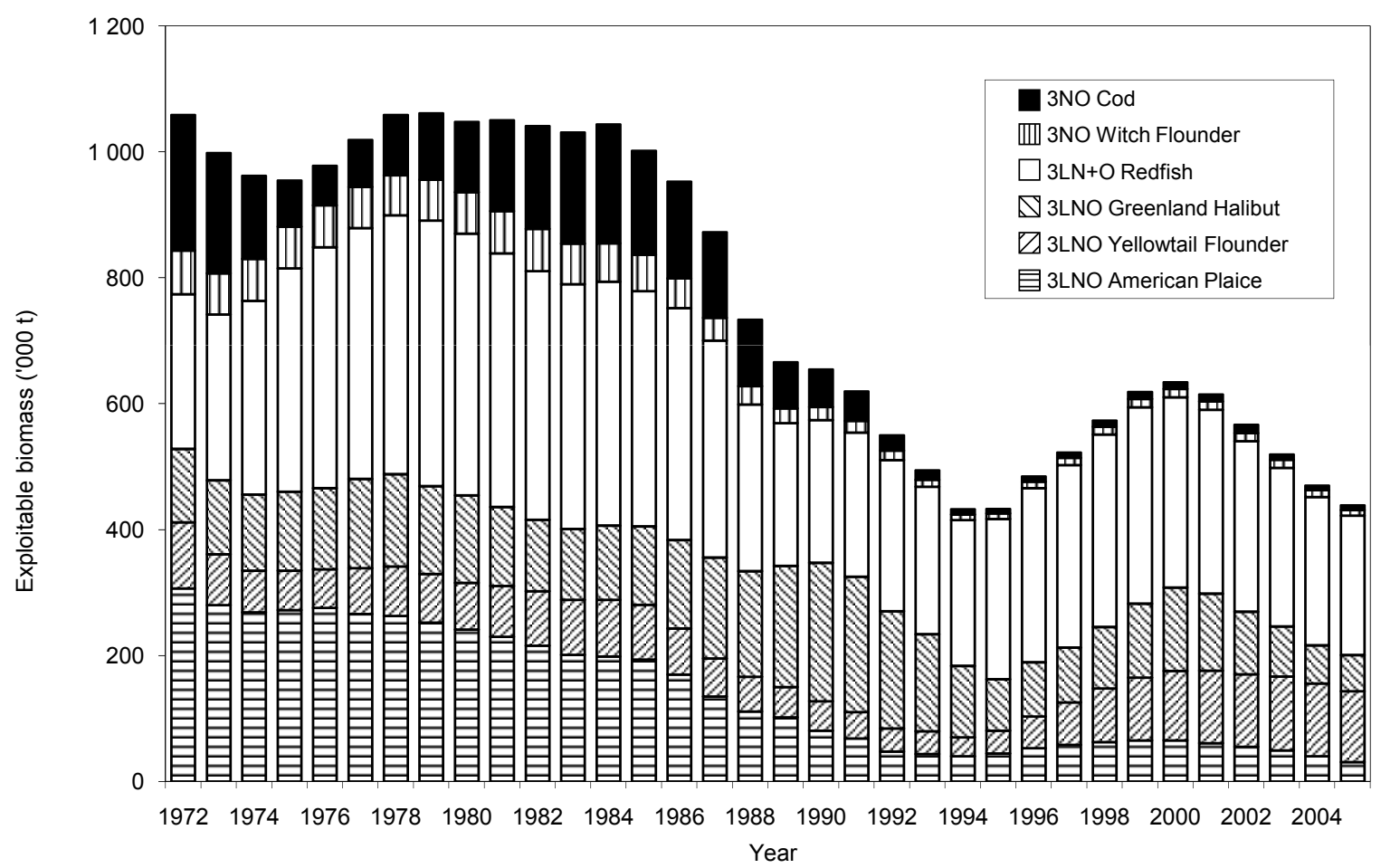

Fig. 4. Annual exploitable stock biomass for six NAFO assessed stocks at the beginning of the year (Brodie et al., MS 2004; Darby et al., MS 2003; Dwyer and Morgan, MS 2004; Healey et al., MS 2003; Morgan et al., MS 2003; Parsons, MS 2004; Power, MS 2003a, MS 2003b). 


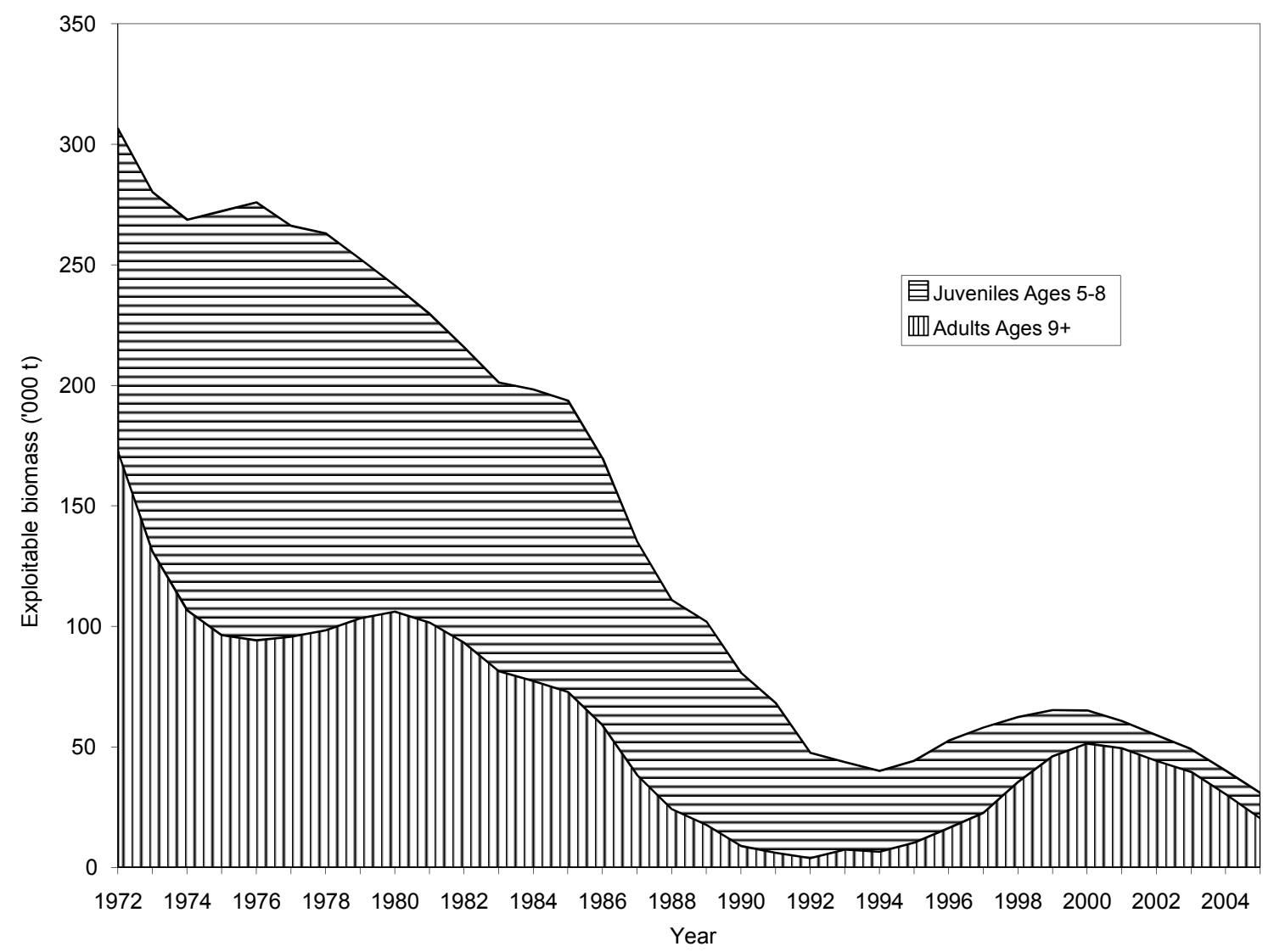

Fig. 5. Divisions 3LNO American plaice exploitable population biomass at the beginning of the year (Morgan et al., MS 2003; Dwyer and Morgan, MS 2004; González Troncoso et al., MS 2004).

on initial stocks distribution data in Morgan et al. (MS 2003). These data also included weight-at-age statistics and the partial recruitment vector. The results were calibrated to VPA estimates provided in Morgan et al. (2003) on start of year biomass and the fishing mortality schedule. Fig. 5 provides a graphic of estimated annual exploitable 3LNO American Plaice biomass (ages 5+) corresponding to SCR revised annual catch (status quo scenario) data.

Fig. 5 illustrates for the 3LNO American plaice stock, a decline typical of other groundfish stocks on the Grand Banks stock from the beginning of the study period, 1972 to the early 1990s. By 1992, estimates for the spawning stock biomass for American Plaice were the lowest on record. In 1995, NAFO declared that this stock be subject to: "no directed fishing", and "bycatches should be kept at the lowest possible levels". While critics have labeled this to be a "catch moratorium" (e.g., SPCFO, 2002), the conditions are such that catches of American plaice may be allowed to continue under some conditions, e.g., as a "non-directed bycatch" of other targeted groundfish stocks. As for other groundfish stocks, following the restricted catch conditions for American plaice, fishing fleets effectively retreated from the Grand Banks between 1995-2000 during which time the estimated abundance of the stock improved. Subsequent to 2000 , and even under the continued catch restrictions, catches of American plaice on the Grand Banks increased, resulting in estimated further declines in the stock to low levels. In the 2002 NAFO Scientific Council report, STACFIS noted concern for increasing catches since 1995 of American plaice despite restrictive fishing measures ("no directed fishing"). These increases were attributed to increases from bycatches in the unregulated fisheries for skate, and for the fisheries under quota of Greenland halibut and yellowtail flounder. Of particular concern for this stock in recent years is the reduced level of recruitment of juveniles (Fig. 5).

\section{Annual Catch Scenario Module Results}

Canadian catches. Fig. 6 illustrates the importance of the Canadian fleet activity in the early part of the study period from 1972-1994 after which NAFO catch restrictions were applied to several Grand Banks stocks. During this initial period, the Canadian fleets operating 


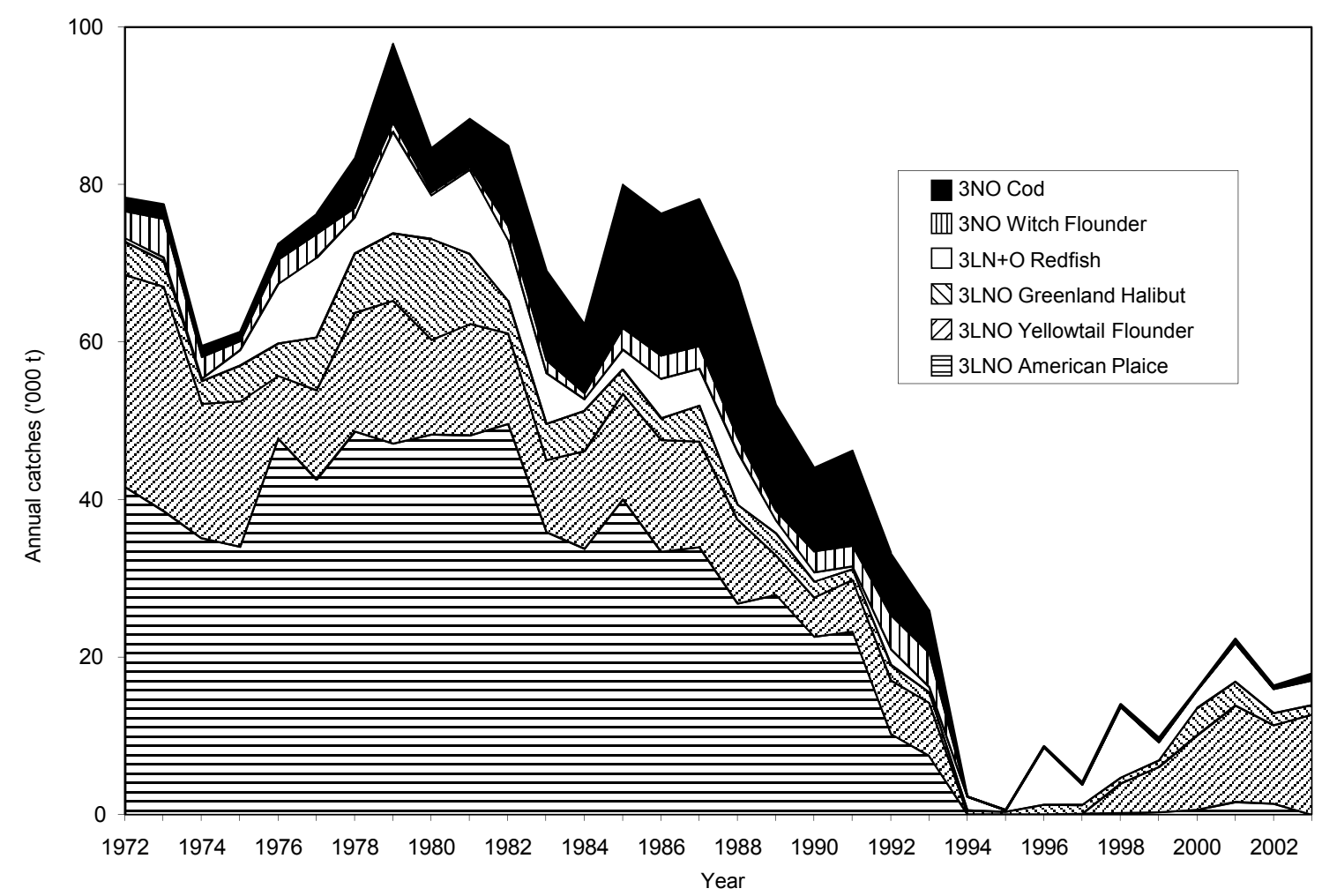

Fig. 6. Annual reported catches by Canada (Maritimes and Newfoundland) (STATLANT 21A database, http://www. nafo.int/fisheries/frames/fishery.html).

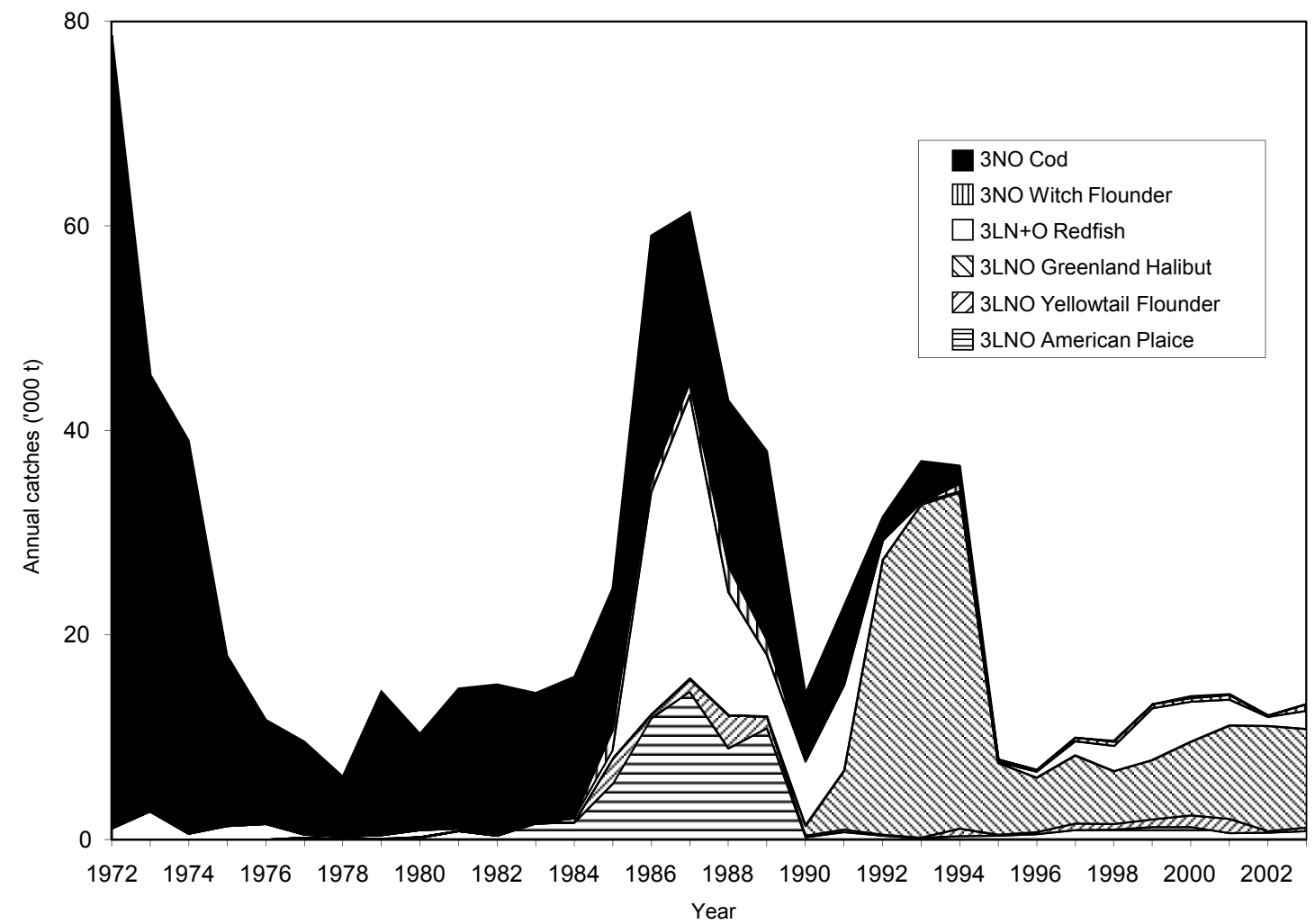

Fig. 7. Annual reported catches by EU-Spain (STATLANT 21A database, http://www.nafo.int/fisheries/frames/ fishery.html). 
in 3LNO were involved in all six fisheries with particular emphasis on American plaice, yellowtail flounder, cod, redfish, Greenland halibut, and witch flounder, in that order. Canadian catches of Grand Banks groundfish ranged between $60000 \mathrm{t}(1974)$ and nearly $120000 \mathrm{t}$ (1979) and averaged about 70000 t from 1972 to 1993. After 1994-1995, Canadian fleet catches were limited to NAFO fisheries that had remained open, namely, redfish, Greenland halibut, and after 1998, an increasing yellowtail flounder fishery when that fishery was reopened by NAFO. Annual catches from 1996-2003 averaged about $10000 \mathrm{t}$.

Spanish catches. The annual Status quo catch Scenarios by stock for the Spanish fleet are illustrated in Fig. 7. Fig. 7 shows an almost exclusive Spanish fleet reliance on 3NO cod in the early study years from 1972-1983 after which time catches began on American plaice, yellowtail flounder, and redfish. During this initial period, catches varied considerably with peaks in 1972 of approximately $75000 \mathrm{t}$ (cod), and again in 1986 and 1987 when total recorded catches surpassed $60000 \mathrm{t}$ (comprised primarily of cod, redfish, and American plaice). From 1975-1984, catches (cod) were less than $15000 \mathrm{t}$ annually.

By the early 1990s, yellowtail flounder catches by Spain were replaced by large increases (20 000-30 000 t) in the Greenland halibut fishery. In 1995, catches of cod, yellowtail flounder, and American plaice disappeared from the Spanish catch mix. These catches were replaced thereafter by ongoing catches of Greenland halibut (approximately 5 000-10 $000 \mathrm{t}$ annually) and increasing recorded catches of redfish, yellowtail flounder, and American plaice up to the year 2000 after which catches in all stocks declined slightly. Since 1995, Spanish recorded catches in all Grand Banks groundfish stocks averaged about $10000 \mathrm{t}$, down considerably from the 1985-1994 period when catches averaged nearly 30000 t. In 2005, Spanish activity on the Grand Banks declined significantly.

Portuguese catches. Annual recorded catches of Grand Banks groundfish by Portugal from 1972 are shown in Fig. 8. As for Spain, Portuguese catches at the beginning of the study period were almost exclusively $3 \mathrm{NO}$ cod. These catches peaked in 1972 at over $10000 \mathrm{t}$ and declined steadily to less than $1000 \mathrm{t}$ in

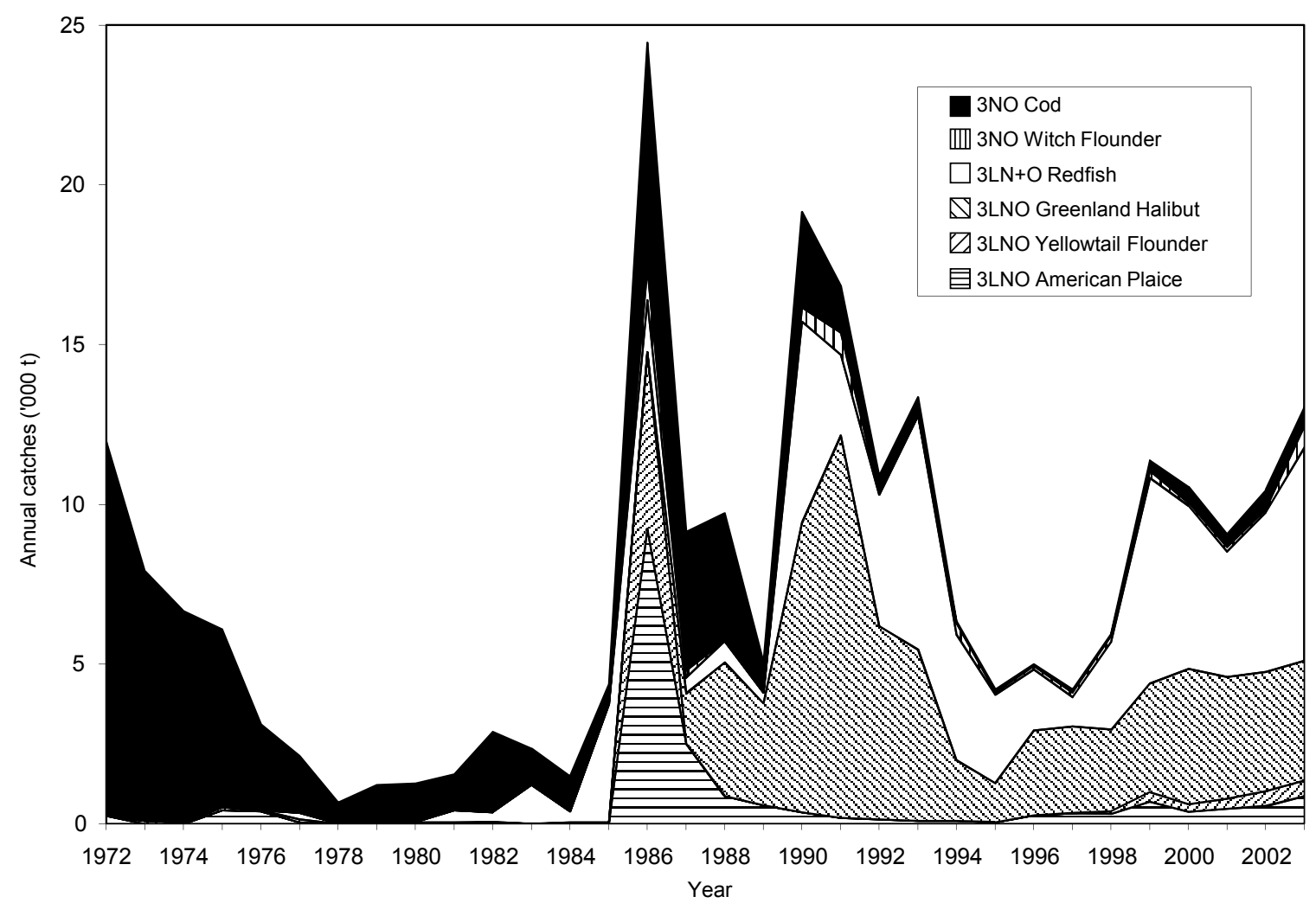

Fig. 8. Annual reported catches by EU-Portugal (STATLANT 21A database, http://www.nafo.int/fisheries/frames/ fishery.html). 
1978. In 1981, the Portuguese fleet began to record small catches of redfish that persisted throughput the period increasing in 1990 and again after the return of the Portuguese fleet following the NAFO imposed catch restrictions on Grand Banks stocks of 1995.

Recorded catches by Portugal show a substantial increase in fishing effort in 1986 when American plaice and yellowtail flounder catches of over $5000 \mathrm{t}$ each were recorded. After 1986, the Portuguese fleet focused their attention on Greenland halibut and catches of this stock rose dramatically reaching a peak in 1991 of over 10000 t. Catches of Greenland halibut by the fleet have continued annually at approximately $2000-3000 \mathrm{t}$. Low levels (less than $1000 \mathrm{t}$ ) of catches are also recorded for the moratoria stocks cod and American plaice since the 1995 catch restrictions on these stocks.

Portuguese total catches in the Grand Banks NRA are one-half to one-quarter that of the Spanish and the Canadian fleets, respectively over all groundfish stocks. Average annual recorded catches by the Portuguese fleets are less than 10000 t over the whole study period (versus $25000 \mathrm{t}$ and $40000 \mathrm{t}$ averages for the Spanish and Ca- nadian fleets, respectively). However, since 1995, annual catches by Portugal are similar to the Spanish fleet totals (approximately $10000 \mathrm{t}$ ) and about one-half that of the Canadian fleet (at approximately 20000 t, Fig. 6).

\section{Fleet Performance Module Results}

The annual economic performance of the fleet segments is estimated from computing standard business reports for profitability, cash, and net worth (assets less liabilities). Operations which exhibit positive profits, ongoing working capital and cash, and increasing assets over liabilities are judged to be economically viable. The model calculates standard business reports for the fleets' harvesting and processing operations.

Canada. Table 5 presents the estimated integrated operations profit statement summary for harvesting and processing operations of the Canada Newfoundland fleet for the annual period from 1998-2003. This report shows that the overall integrated operations of the Newfoundland sector contribute to fixed costs, i.e., the annual net operating income is positive, ranging from nearly $\$ 40$ million to almost $\$ 90$ million for the fleet overall. After fixed cost items (licensing, insurance, deprecia-

TABLE 5. Summary integrated annual profit statement (\$ '000) for Canada Newfoundland 1998-2003.

\begin{tabular}{lrrrrrr}
\hline \hline & 1998 & 1999 & \multicolumn{1}{c}{2000} & 2001 & \multicolumn{1}{c}{2002} & \multicolumn{1}{c}{2003} \\
\hline Gross revenue & 62484 & 58454 & 92572 & 132084 & 95697 & 112265 \\
& & & & & & \\
Total material and supplies & 9295 & 9295 & 13426 & 19623 & 14459 & 18590 \\
Miscellaneous costs & 225 & 225 & 325 & 475 & 350 & 450 \\
Total cost of goods & 1700 & 1462 & 2405 & 3583 & 2650 & 3201 \\
& & & & & & \\
Total harvesting labour costs & 5110 & 4322 & 7308 & 10692 & 8076 & 8976 \\
Total processing labour costs & 5099 & 4386 & 7216 & 10749 & 7950 & 9602 \\
Total integrated labour costs & 10209 & 8708 & 14524 & 21441 & 16026 & 18577 \\
& & & & & & \\
Cost of operations & 21203 & 19465 & 30355 & 44647 & 33135 & 40368 \\
& & & & & & \\
Net operating income & 41280 & 38989 & 62217 & 87437 & 62562 & 71896 \\
& & & & & & \\
Total other expenses & 19828 & 20504 & 21700 & 25274 & 23786 & 24141 \\
Total costs & 41032 & 39968 & 52056 & 69921 & 56921 & 64509 \\
Profit (before income taxes) & 21452 & 18485 & 40516 & 62163 & 38776 & 47755 \\
Income tax payable & 10726 & 9243 & 20258 & 31081 & 19388 & 23878 \\
Net profit after taxes & 10726 & 9243 & 20258 & 31081 & 19388 & 23878 \\
\hline
\end{tabular}


TABLE 6. Summary integrated annual profit statement (\$ '000) for the EU-Spain fleet 1998-2003 assuming Status quo catch scenario.

\begin{tabular}{|c|c|c|c|c|c|c|}
\hline & 1998 & 1999 & 2000 & 2001 & 2002 & 2003 \\
\hline Gross revenue & 50853 & 66919 & 73040 & 67102 & 50981 & 57613 \\
\hline Total material and supplies & 27220 & 36747 & 40830 & 40830 & 34025 & 35386 \\
\hline Miscellaneous costs & 500 & 675 & 750 & 750 & 625 & 650 \\
\hline Total cost of goods & 1954 & 2635 & 2948 & 2896 & 2452 & 2731 \\
\hline Total harvesting labour costs & 9397 & 8370 & 8960 & 8909 & 9204 & 12348 \\
\hline Total processing labour costs & 4689 & 6324 & 7076 & 6950 & 5884 & 6555 \\
\hline Total integrated labour costs & 14086 & 14695 & 16035 & 15859 & 15088 & 18903 \\
\hline Cost of operations & 43260 & 54077 & 59813 & 59585 & 51565 & 57020 \\
\hline Net operating income & 7593 & 12842 & 13227 & 7517 & -584 & 593 \\
\hline Total other expenses & 30016 & 37463 & 41411 & 41709 & 36014 & 36387 \\
\hline Total costs & 73276 & 91540 & 101224 & 101294 & 87579 & 93407 \\
\hline Profit (before income taxes) & -22423 & -24621 & -28184 & -34192 & -36598 & -35794 \\
\hline Income tax payable & -11212 & -12311 & -14092 & -17096 & -18299 & -17897 \\
\hline Net profit after taxes & -11212 & -12311 & -14092 & -17096 & -18299 & -17897 \\
\hline
\end{tabular}

tion, repair and maintenance, and interest expense on debt), profits over 1998-2003 are positive with a range between \$9 million (1999) and \$31 million (2001) when Newfoundland catches were buoyed by high catches of yellowtail flounder at good prices.

Spain. The annual statement of profit under the Status quo catch scenario from integrated harvesting and processing operations of the Spanish fleet report gross revenues of between $\$ 50$ and $\$ 73$ million for 1998-2003 (Table 6). For 2003, Varela-Lafuente et al. (2004) report that "NAFO Income" (Gross Revenue) from Spanish fishing activity (assuming 30 active vessels) amounts to $€ 49$ million, or approximately CDN $\$ 73$ million (at an exchange rate of $€ 1=C D N \$ 1.50)$. Given that Spanish fishing in NAFO also includes other stocks not part of this study, then the estimated Gross Revenue of \$58 million is a reasonable approximation of Spanish earnings from the six Grand Banks groundfish stocks in 3LNO.

Similarly, for 2003, operating costs are estimated at $\$ 57$ million for the Spanish fleet or approximately $€ 38$ million. This is comparable to the Varela-Lafuente et al. (2004) estimate of "Total Costs" of $€ 64$ million for a
Spanish fleet of 30 vessels fishing all stocks in the Northwest Atlantic NAFO NRA including 3M (Flemish Cap).

Table 6 reveals that the Spanish fleet at the Status quo catch scenario is only marginally contributing to fixed costs over the period 1998-2003. Contributions occur in those years that show positive Net Operating Incomes (NOI) where contributions to fixed costs range from a loss of \$0.5 million in 2002 to a peak at \$13 million (2000). In all years, the significant other expenses for fixed costs, depreciation of capital, repairs, and interest cost, result in profits (before and after taxes) becoming negative (losses) between \$11-18 million annually.

The poor economic performance of the Spanish fleet in 2002 and 2003 (profit loss of \$18 million) is attributed to the lower revenues from declining catches in redfish and yellowtail flounder combined with a fall in prices (Table 4) for Greenland halibut amidst increases in Greenland halibut catches.

Portugal. Table 7 provides model estimates for gross revenues of \$62 million for 2003 for the Portuguese fleet under the Status quo catch scenario. This 
TABLE 7. Summary integrated annual profit statement ( $\$$ '000) for the EU-Portugal fleet 1998-2003 assuming Status quo catch scenario.

\begin{tabular}{lrrrrrr}
\hline \hline & 1998 & 1999 & \multicolumn{1}{c}{2000} & \multicolumn{1}{c}{2001} & \multicolumn{1}{c}{2002} & \multicolumn{1}{c}{2003} \\
\hline Gross revenue & 29836 & 57336 & 54798 & 43376 & 48518 & 62458 \\
& & & & & & \\
Total material and supplies & 10470 & 19632 & 18323 & 15706 & 17014 & 18323 \\
Miscellaneous costs & 200 & 375 & 350 & 300 & 325 & 350 \\
Total cost of goods & 951 & 1818 & 1810 & 1464 & 1652 & 2106 \\
& & & & & & \\
Total harvesting labour costs & 5790 & 7545 & 7254 & 6116 & 7333 & 9918 \\
Total processing labour costs & 2852 & 5455 & 5431 & 4392 & 4957 & 6317 \\
Total integrated labour costs & 8643 & 13000 & 12685 & 10509 & 12291 & 16236 \\
& & & & & & \\
Cost of operations & 20064 & 34450 & 32819 & 27678 & 30958 & 36664 \\
& & & & & & \\
Net operating income & 9772 & 22886 & 21980 & 15698 & 17560 & 25794 \\
Total other expenses & 14341 & 23166 & 23106 & 20737 & 21666 & 23131 \\
Total costs & 34405 & 57617 & 55925 & 48416 & 52624 & 59795 \\
Profit (before income taxes) & -4569 & -280 & -1127 & -5040 & -4106 & 2663 \\
Income tax payable & -2285 & -140 & -563 & -2520 & -2053 & 1332 \\
\hline & -2285 & -140 & -563 & -2520 & -2053 & 1332 \\
\hline
\end{tabular}

equates to almost $€ 42$ million at an exchange rate of $1 €=\$ 1.50 \mathrm{CDN})$. The report on the Portuguese "NAFO Trawlers" (EC, MS 2004) gives revenues as only $€ 31.3$ million for 2003 suggesting that model revenues are overestimated. EU report estimates for major costs items of "Fuel costs" ( $€ 7.6$ million) and "Crew share" ( $€ 11.6$ million) are comparable to the model estimates of $€ 8.9$ million ( $\$ 13.4$ million) and $€ 8.4$ million (\$12.6 million) for 2003.

As for the Spanish fleet segment, the EU Portugal fleet is not profitable under Status quo catches from 1998-2002 (Table 7). However, in each year, the Net Operating Income (NOI) is positive, contributing from \$10-26 million annually toward meeting fixed costs. Fixed costs and the assumed costs of capital reduce profitability to close to zero or below from 1998-2002. These losses are attributed to increased catches in redfish and Greenland halibut toward the later part of the period (2002) but under declining prices for these stocks (Table 4). Similarly, positive profits for 2003 come from still higher increases in recorded redfish and Greenland halibut catches despite the decline in unit prices.
Increased EU catches. Increased catch scenarios arise from a doubling of the assumed daily catch rates by the EU fleets. The doubling of catches by species results in an approximate doubling of gross revenues to over $\$ 100$ million annually for the Spanish fleet compared with Table 6 . The cost of labour also doubles to roughly $\$ 30$ million annually as a function of the increased catches and landed value.

Net Operating Income (and contribution to fixed costs) improves by over $\$ 30$ million annually compared to the Status quo catch scenario for the Spanish fleet. However, other expenses for fixed costs, depreciation, annual repairs, and interest expense result in declining profits from 1999-2001 and after tax profits become negative in 2002 and 2003 with expected losses reaching \$4 million in 2003.

Overall, the increased catch scenario applied to the Spanish fleet in 3LNO improves the operation of the fleet and this is reflected as contributing annually to fixed costs. However, the assumed capital costs of the 30 vessel fleet negate annual positive profits, especially 
in the latter years, 2002 and 2003. Thus, the Spanish fleet is considered marginally profitable over the 1998-2003 period with a tendency toward losses by the end of this period due to high relative capital and fixed costs. (This apparent trend may help explain the withdrawal of the Spanish fleet on viability grounds in 2005.)

Increased catches to the Portuguese fleet result in improved viability for the operations of this fleet. Similar annual fleet gross revenues to the Spanish fleet, coupled with lower relative fixed costs and costs of capital to support a smaller fleet result in profitable operations earning \$10-20 million in after tax profits annually.

Increased EU small fish catches. As in the previous scenario, increased small fish catches scenario assumes catch rates applied to fishing on Grand Banks 3LNO stocks are twice that assumed for the Status quo catch scenario. As well, catches of "small fish" at ages younger than the Status quo scenario for all six groundfish stocks are assumed in the distribution of annual catches by Spain and Portugal.

Compared to the Status quo catch scenario, gross revenues are estimated to increase by approximately $60 \%$ annually from the doubling of catch by weight. This is a consequence of the allocation of smaller fish catches to lower valued production (e.g., blocks, meal, fish oil, etc.) as opposed to higher valued fillets and whole or dressed fish. The costs of operations (e.g., labour, fuel, provisions) for this catch scenario are similar to the costs of the increased catch scenario. This results in positive net operating income throughout the period ranging from $\$ 16$ million (2002 and 2003) to \$50 million (2000). However, high other expenses for fixed and capital costs results in low annual profits and losses in the later years, 2002 and 2003.

For the Spanish fleet overall, catching fish at younger ages would appear to forego yield and result in a more precarious economic viability position than otherwise. This is a consequence of catches focused on Greenland halibut where prices are estimated to fall over the period for Greenland halibut fillets (Table 4).

For Portugal under increased small fish catches, gross revenues are estimated to increase by approximately $75 \%$ annually from the doubling of catch by weight with emphasis on small fish compared to the Status quo catch scenario. Whereas Spanish revenues only increased by approximately $60 \%$, the $75 \%$ increase in Portuguese revenues is attributed to the mix of more highly-valued redfish in the Portuguese catches versus more Greenland halibut (at lower and declining prices) in the Spanish catches.

The costs of operations (e.g., labour, fuel, provisions) for this catch scenario are similar to the costs of the increased catch scenario. The net result is positive net operating income throughout the period ranging

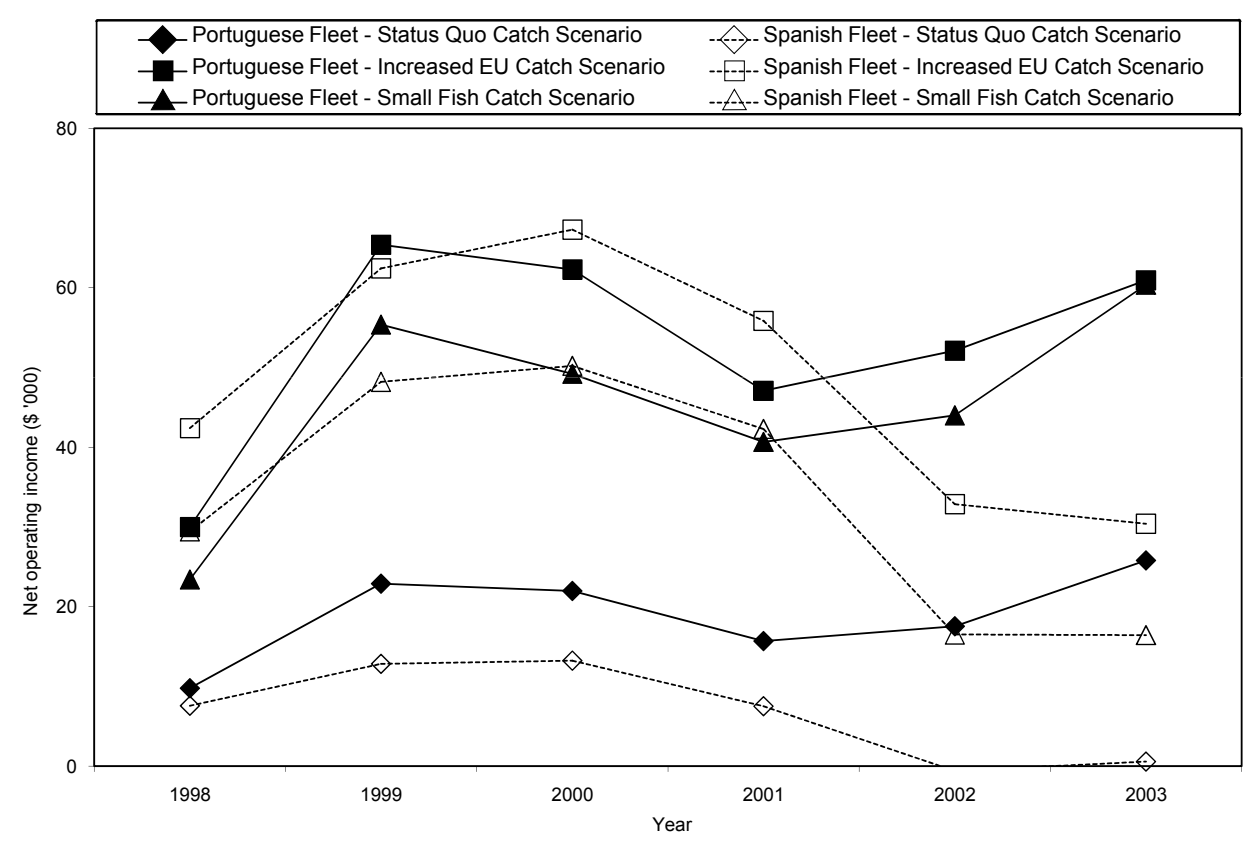

Fig. 9. Net operating income for EU Fleets under different catch scenarios in Canadian dollars. 
from \$23 million in 1998 and increasing to \$60 million by 2003. Other expenses for fixed and capital costs results in annual after tax profits between $\$ 4$ million in 1998 ranging up to $\$ 17$ million by the end of the period in 2003. Fig. 9 summarizes the annual impact on Net Operating Income for the Spanish and Portuguese fleets of the Status Quo, Increased Catches, and Increased Small Fish catches scenarios.

\section{Canadian Communities Socioeconomic Module Results}

The economic performance of the Canadian fleets includes the costs of engaging labour resources for harvesting (crews and captains) and for processing (loading and unloading, cutting, packaging). The participation of the domestic Canadian communities are implied by the labour requirements for harvesting and processing annual catches by species in the Grand Banks groundfishery system attributed either to the Newfoundland or the Maritime fleet segments and their associated communities.

Fig. 10 illustrates the annual total calculated labour earnings for harvesting and processing the total catch- es by the Canadian Newfoundland and Labrador fleet. These labour measures assume hourly costs of labour, total employment hours as a function of catches, and an assumed rate of transformation from landed fish to final product.

Labour requirements are highly correlated with total catches by the Canadian fleets operating on the Grand Banks (Fig. 6). In particular, the decline in employed labour from the Grand Banks fishery from the mid-1980s to a near complete disappearance of the sector by 1994 , follows the decline in the Canadian fleet segments catch totals for this same period. For the affected Canadian communities, the rise in labour requirements after 1998 is primarily the result of increased catches of yellowtail flounder after the lifting by NAFO of the catch restrictions on this stock (Fig. 5).

Communities in Nova Scotia and Newfoundland that participated in the Grand Banks fishery since 1972 have all experienced similar demographic trends related to their dependence as coastal communities on the fishery. These trends are applicable to the smaller coastal

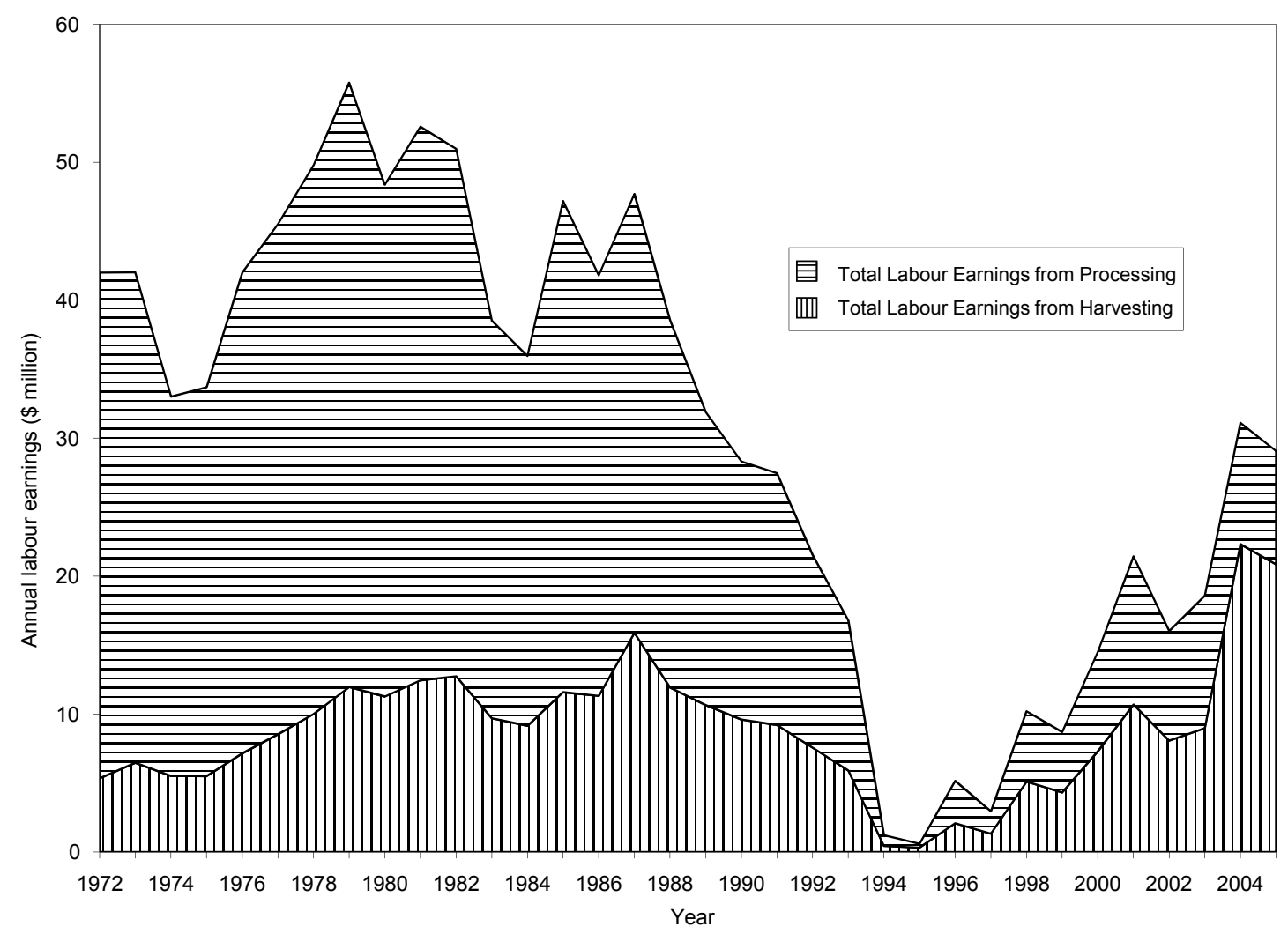

Fig. 10. Annual labour earnings for harvesting and processing for Newfoundland in Canadian dollars. 
Canadian communities and are not relevant to the larger cities of St. John's, Halifax, and Sydney. The Canadian community trends may be divided into three main periods: Growth: 1972-1983, Decline: 1984-1994, and Freefall: 1995-2005.

Growth: 1972-1983. This was the period of largest annual fishing catches (Fig. 6) and labour participation (Fig. 10) by the Canadian fleets in the Grand Banks multispecies groundfish fishery. The period overlapped the introduction of extended jurisdiction and the 200 mile limit of the coastal state in 1977. It was a period of high optimism and subsidized harvesting and new processing investment for the domestic Canadian fishery (Munro, 1979) signifying a period of growth in the fishing sector in general, and the Grand Banks fishery, in particular. The industry restructuring of the Kirby Report (TFAF, 1982) that took place following the over-investments in processing and the negative impacts of the global inflation of the late 1970 s, reoriented the traditional fishery and paved the way for fully integrated fishing operations capable of competing at the global level. This was also a period of strong resource base in all stocks and there was considerable optimism for future stock growth. The period was also marked by reduced fishing activity by distant water fleets due to UNCLOS and the 200 mile EEZ for Canada that covered all but the Nose and Tail of the Grand Banks. Under ICNAF, and until NAFO replaced this body in 1979, foreign fleets where at this point, searching for new high seas fishing grounds to renew their fleet activities. While the EU fleets of Spain and Portugal remained involved primarily in the cod fishery over this period, these fleets had not yet become involved in the multispecies fishery of the Grand Banks (Figs. 7 and 8).

Decline: 1984-1994. The beginning of this period, 1985-1986, marked a major turnaround in industry fortunes following the restructuring in the east coast fishing sector. More reasonable operating costs (for fuel) and good markets for fish products, especially in the U.S. (following claims of favourable health consequences from eating fish) led to an early repayment of many government subsidies by the new vertically integrated companies in Newfoundland and Nova Scotia. As well, Canadian scientists continued their optimism about the future of the east coast groundfish resources based on survey data. This period also marked the reappearance of the EU fleets from Spain and Portugal in the 3LNO Grand Banks but this time in multispecies groundfish fisheries. With the increased fishing activity on all stocks by the EU fleets and, the continued fishing pressure on all stocks by Canadian vessels, total catches of the six
Grand Banks groundfish species by all fleets peaked at over $250000 \mathrm{t}$ (1987) and employment in the domestic communities was estimated at over 2000 PYs in support of this fishery. Following this peak, after 1987, catches in $3 \mathrm{LNO}$ fell off dramatically. When the $2 \mathrm{~J} 3 \mathrm{KL}$ cod fishery closed in 1992, the future of the Grand Banks multispecies groundfishery was already determined. By 1994, the Canadian fleet was fishing small amounts of redfish and Greenland halibut in 3LNO amounting to less than $2000 \mathrm{t}$ overall and corresponding employment was estimated at only 100 PYs in Nova Scotia and Newfoundland combined to support the Grand Banks groundfishery. While the EU fleet remained active up to the end of this period, their catch distribution had diversified into redfish (Portugal) and Greenland halibut (Spain). Ultimately, NAFO took the radical step of setting directed catch moratoria on 3LNO American plaice, 3LNO yellowtail flounder, $3 \mathrm{NO}$ cod, and $3 \mathrm{NO}$ witch flounder for the 1995 season. These developments in the fishery had the predicted impact on the domestic Canadian fish harvesting and processing sectors (SSCFO, 1995). Plant closures, population emigration in search for employment elsewhere (e.g., the Alberta oil fields) and declines in local community populations were the consequence of the resource declines in the Grand Banks fisheries. Employment in the Grand Banks fishery bottomed out in 1994-1995 at approximately 20 PYs from total groundfish catches of redfish and Greenland halibut of only about 500 t (Figs. 6 and 10).

Freefall: 1995-2005. The Estai affair of March 1995 (DFO, 1995) brought public attention to the NAFO catch restrictions and the alleged IUU fishing that had been taking place on the Grand Banks. The effect was to reduce the activity of all fishing fleets in 3LNO as well as on the Nose and Tail of the Grand Banks to around $10000 \mathrm{t}$ for the combined Canadian and EU fleet removals. After 1996, fishing continued at low levels by the Canadian Newfoundland fleet until 1998 when catches reached over $10000 \mathrm{t}$ on a mixture of redfish and yellowtail flounder, rising to $20000 \mathrm{t}$ by 2001 (Fig. 6). These catch increases signaled a corresponding rise in harvesting and processing labour estimated at 500-800 PYs in Newfoundland communities.

The changes described in the Grand Banks fishery over the period from 1972 were instrumental in affecting the participating communities. Throughout the period, governments, industry, and the communities were under considerable scrutiny as repeated attempts were made to shift into opportunities not directly tied to the Grand Banks fisheries, while at the same time, encountering considerable resistance to changing the 
historical connections and the belief that the fishery would inevitably rise again. While the decline of the Grand Banks' groundfish resources after 1984 were not the only events affecting the communities (positively or negatively), the resolute dependence of the communities on the fishery remains the driving force behind the shifts that are still being experienced in these coastal communities "under stress" today (Woodrow, 2004; SSCFO, 2005).

\section{Discussion}

\section{EU Fleet viability}

The question about the economic viability of the EU fleets operating on the Grand Banks in recent years is based on assumptions for EU fleet catch statistics and the operating and capital costs of the EU fleets. The assumptions on catches by the EU fleets indicate that the recent 2003 mix of Portuguese fleet catches by species (with its focus on $51 \%$ of annual catch of redfish) is more conducive to profitability than that of the Spanish fleet with its targeting on Greenland halibut (72\% recorded in 2003). This conclusion is grounded on product disposition and species-product prices (Table 4).

The larger number of vessels in the Spanish fleet implies higher fixed costs, repair and maintenance, and capital costs reducing overall profitability, ceteris paribus, compared to the Portuguese fleet. These expenses are assumed to amount to $\$ 28$ million for the Spanish fleet in 2003 and only $\$ 23$ million for the Portuguese fleet. However, there is considerable uncertainty associated with actual fixed costs and capital requirements for the EU fleets. Reported data by EU sources appear to underestimate "depreciation", "interest", and "capital costs" to NAFO activities (EC, MS 2004; DFO, unpublished data). Subsidization by home governments for capital construction, employment, capital depreciation, and fuel consumption may adjust these costs considerably for the EU fleets.

On the question of economic viability of the fleets, it is undeniable that fishing operations on the Grand Banks contribute to covering fixed and capital costs of the EU fleets. The mere presence of these fleets on the fishing grounds is evidence that the opportunity costs of fishing elsewhere, or not fishing at all, exceed the costs of fishing on the Grand Banks (after all known subsidies are also considered). However, the extent of the actual contribution margin is difficult to ascertain. Pro-rating of estimated Canadian fleet data on operating costs to the EU fleet provides a general indication that compliance fishing is marginally profitable. Under these circumstances, catching more fish would improve fleet viability still fur- ther. From a simple evidence-based analysis of the real costs of IUU fishing and the minimal extent of actual prosecutions for fisheries violations on the high seas, it would be reasonable to assume that decisions made by captains on the water to fish outside compliance are costeffective decisions. Hence, we can state that under the current NAFO management system, vessels (Canadian, Spanish, and Portuguese, and all others) that fish illegally are likely to be more profitable than those that comply with the regulations even after fines and prosecutions have been rendered.

\section{Community action: overview of policy}

Coastal communities are continuing their population "free-fall" in spite of substantial income support and adjustment programs that, arguably, have not been fully effective. Reasons for this include the fact that these programs have been designed as: (1) stop gaps in what is hoped will be temporary setbacks that will be corrected within short-term political time frames; and (2) implicit means to restore communities to sustainability and growth using traditional dependences but without relying on a strong fisheries resource base.

Despite recognizing the importance of co-management and shared stewardship, the Canadian federal government is unwilling to relinquish the ultimate authority of the Minister of Fisheries and Oceans to grant access and allocation of fisheries as "a common property resource" (DFO, 2007a). In our opinion, until some other system of equitable distribution of resources is defined that will grant responsibilities directly to the resource exploiters (communities and industries) for the right to make their own decisions relative to the fisheries, then exploiters will continue to understand that success is brought through effective lobbying of governments for access and allocation to increase their shares in competition with others. Collectively, rational behaviour of this kind, adopted by all communities especially when fish resources have declined, leads to a continuing cycle of short-term government support. The consequences are that governments' inability to define clear, strategic objectives and to take decisive but unpopular decisions will continue the drain on all coastal communities..

Geographical proximity to available marine resources as well as to markets minimize the opportunities for some communities especially in industries that compete for shares in global markets. Arbo and Hersoug (1997) consider the economic opportunities available to coastal communities in the context of competing in a highly competitive global marketplace that is becoming the norm in markets for food from the sea. The need to operate efficient integrated operations close to mar- 
kets impacts on the possibilities for some coastal communities to attract entrepreneurs who typically hold the government's promise of access to the resources tied to the promise of employment and economic growth. Existing centres of higher population that already support infrastructure for international transportation of goods become preferred centres of attraction for investment in fisheries for competitive international trade despite government subsidies to relocate elsewhere. This diminishes the opportunities of many coastal communities that may once have been subsidized to operate facilities when resources were plentiful and supplies were secure.

The noted decline in Canadian coastal community populations only tell part of the story evolving in these communities. Dependence on the fishery as the chief reason for population declines means that community residents who are potential fishery workers are responsible for the population out-migration. Potential fisheries workers are mobile workers often skilled, educated, and young as the modern technological demands of the fishery would require, i.e., groups of 20-39 years of age (Woodrow, 2004). Consequently, the composition of the remaining population of coastal communities represents aging and less mobile residents with fewer economic opportunities and a reduced ability to attract new capital. Overall, this signals a loss of hope in the future for many coastal communities.

\section{NAFO Approach}

The integrated modeling and analysis of stocks, fleets, and communities reveal conflicts within a system that deflects the NAFO management system from achieving its stock sustainability mandate on the Grand Banks due to other objectives for economic and social stability. The evidence shows there is incentive for greater than desired stock exploitation leading to declines in resource status despite measures designed to "rebuild" stocks (Shelton, MS 2005). Integrated analysis requires that the influences and incentives of each of the participants be quantified with respect to the performance of all aspects of the system. What is evident then is that the integrated system must balance multiple and often conflicting, but logical objectives. Individual decisions made on the basis of profit motivation may contradict the overall NAFO objective of sustainable stocks objectives and need to be considered in the application of effective management policy. This attests to the need for compliance of contracting parties through better management control mechanisms and shared management responsibilities.

Understanding the drivers of the fishery system participants and the need to incorporate these drivers in NAFO management policy is indicated as being far more important for realizing objectives than a complete understanding of the ecosystem. Accordingly, this study suggests that more emphasis be established on controlling the activities of contracting members versus committing to "applying an ecosystem approach to fisheries management in the Northwest Atlantic area which includes safeguarding the marine environment, conserving its marine biodiversity, minimizing the risk of long term or irreversible adverse effects of fishing activities in the area, and taking account of the relationship between all components of the ecosystem" (Article 2 of NAFO, MS 2007). A more precise science-based understanding of stock and ecosystem dynamics will not be helpful without a balanced management control of the fishing exploitation activities of the fleets.

The argument that the decline in groundfish stocks on the Grand Banks is due solely to "foreign overfishing" is a simplification, and one that is not fully justified given Canada's extensive historical fishing activity (Fig. 6). At the same time, the current responsibility borne by country governments in the NAFO RFMO for the actions of their respective commercial fleets has provided ongoing evidence (e.g., NAFO Regulatory Area (NRA) Enforcement Activity, DFO, 2007b) that stewardship of the fishing grounds is displaced, and that governments cannot effectively speak for, or enforce regulatory compliance, on their fleets on the high seas. Assigning shortterm, annual access rights to countries that in turn award these to commercial entities without giving the industry corresponding responsibility to manage them, is an enticement to noncompliance as firms act on the profit incentive. In the end, it is NAFO and its members who are deemed to be "responsible" rather than the commercial industry fishing under their NAFO country banner. Given the opportunity and the responsibility, the commercial industry might be expected to act strategically and sustainably for their own long-term survival.

Future strategic examinations of the Grand Banks fishery will involve the analysis of the impacts of policy on the multiple criteria of resources' stocks status, commercial viability, socioeconomic sustainability, and administrative costs of regulation. The Grand Banks fishery model provides a template for the analysis of policy scenarios including the impacts of area closures, the restriction of fishing effort, and catch limitations. Futhermore, the need to evaluate the multiple impacts of policy options on the system needs to be carried out in a precautionary framework with clear definitions on policy objectives under uncertainty. Demonstration of integrated strategic policy impacts on all aspects of the complex system provide commercial participants in the high seas 
fishery with a better idea of the consequences of their actions in order that they may take it on themselves to act responsibly while having the burden of responsibility.

\section{Acknowledgements}

The author acknowledges with thanks the contributions of Leo Strowbridge, John Collins, and Paul Cahill of the Department of Fisheries and Oceans in White Hills for their comments, information and insights. Special thanks to Scott Parsons for passing on his knowledge and hands on experience at NAFO, to Bruce Chapman and Brian MacNamara for their feedback on Canadian trawler data, and to Maureen Woodrow and Herb Bown for pointing me to the Newfoundland Community Accounts websites. All errors and opinions expressed in this document remain the sole responsibility of the author. Model software is available on request from the author.

\section{References}

ARDO, P., and B. HERSOUG. 1997. The globalization of the fishing industry and the case of Finnmark. Marine Policy. 21: 121-142. doi:10.1016/S0308-597X(97)83224-1

BRODIE, W. B., S. J. WALSH, M. J. MORGAN, and K. S. Dwyer. MS 2004. An assessment of the Grand Bank yellowtail flounder stock, NAFO Divisions 3LNO, in 2004. NAFO SCR Doc., No. 54, Serial No. N5007, 35 p.

CC. 2005. Communities Demographics. Statistics Canada Census Database for Canada Census 1971, 1976, 1981, 1986, 1991, 1996, and 2001. Census of Canada. http:// www.statcan.ca

DFO. 1995. Canada Seizes Spanish Trawler. Department of Fisheries and Oceans News Release, NR-HQ-95-29E. 9 March 1995. http://www.dfo-mpo.gc.ca/media/newsrel/1995/hq-ac29 e.htm

2004. A Recent Account of Canada's Atlantic Cod Fishery. Department of Fisheries and Oceans. 15 p. http:// www.dfo-mpo.gc.ca/kids-enfants/map-carte/map e.htm

2005a. Statistical Reports - Seafisheries quantity and value reports. Department of Fisheries and Oceans. http://www.dfo-mpo.gc.ca/communic/statistics/commercial/landings/seafisheries/index e.htm

2005b. Statistical Reports - Trade Canadian exports by species, province and market types. Department of Fisheries and Oceans. http://www.dfo-mpo.gc.ca/communic/statistics/trade/canadian trade/export data/index e.htm

2007a. New Fisheries Act. Backgrounders. Department of Fisheries and Oceans. November. http://www. dfo-mpo.gc.ca/media/backgrou/2007/hq-ac59a e.htm.

2007b. NAFO Regulatory Area (NRA) Enforcement Activity, Enforcement Statistics, Overfishing and International Fisheries and Oceans Governance. Department of Fisheries and Oceans. http://www.dfo-mpo.gc.ca/overfishing-surpeche/en_statistics_e.htm.

DARBY, C., W. R. BOWERING, and J.-C. MAHÉ. MS 2003.
An assessment of stock status of the reenland halibut resource in NAFO subarea 2 and divisions 3KLMNO based on extended survivors analysis with short and mediumterm projections of future stock development. NAFO SCR Doc., Serial No. N4883, 64 (Revised), 40 p.

DEMBO, R. S. 1991. Scenario Optimization. Annals of Operations Research. 30: 63-80. doi:10.1007/BF02204809

DWYER, K. S., and M. J. MORGAN. MS 2004. A stock status update of American plaice in NAFO divisions 3LNO. NAFO SCR Doc., No. 47, Serial No. N5000, 24 p.

EC. MS 2002. Economic performance of selected European fishing fleets: annual report 2004. Economic assessment of European fisheries. Concerted Action (Q5CA-200101502), EC, Brussels, 2 p.

MS 2004. Economic performance of selected European fishing fleets: annual report 2004. Economic assessment of European fisheries. Concerted Action (Q5CA2001-01502), EC, Brussels, 295 p.

GONZÁlEZ TRONCOSO, D., C. GONZÁLEZ, and X. PAZ. MS 2004. American plaice biomass and abundance from the surveys conducted by Spain in the NAFO Regulatory Area of divisions 3NO, 1995-2003. NAFO SCR Doc., No. 9, Serial No. N4954, 22 p.

HEALEY, B. P., E. F. MURPHY, D. E. STANSBURY, and J. BRATTEY. MS 2003. An assessment of the cod stock in NAFO divisions 3NO. NAFO SCR Doc., No. 59, Serial No. N4878, $62 \mathrm{p}$.

LANE, D. E., and R. L. STEPHENSON. 1996. SATURN: A framework for integrated analysis in fisheries management. Special Issue of INFOR, 34: 156-180.

LEAR, W. H. 2005. History of Fisheries in the Northwest Atlantic: The 500-Year Perspective. J. Northw. Atl. Fish. Sci., 23: 41-73.

MAY, A. W., D. A. RUSSELL, and D. H. ROWE. 2005. Breaking new ground: an action plan for rebuilding the Grand Banks fisheries. Report of the advisory panel on the sustainable management of straddling fish stocks in the northwest Atlantic. http://www.dfo-mpo.gc.ca/overfishing-surpeche/documents/advisory e.htm

McDIARMID, B., M. GOTJE, and K. SACK. 2005. The Northwest Atlantic Fisheries Organization: a case study in how RFMOs regularly fail to manage our Oceans. Greenpeace, 21 p. http://www.greenpeace.org/international/press/reports/NAFO-Case-Study\#

MOF. 2005. Responsible Fisheries. Information Centre of the Icelandic Ministry of Fisheries. http://www.fisheries.is

MORGAN, M. J., W. B. BRODIE, D. M. PARSONS, and B. P. HEALEY. MS 2003. An assessment of American plaice in NAFO divisions 3LNO. NAFO SCR Doc., No. 56, Serial No. N4874, 70 p.

MUNRO, G.R. 1979. The Promise of Abundance. Report of the Economic Council of Canada.

NAFO. MS 2007. Amendment to the Convention on Future Multilateral Cooperation in the Northwest Atlantic Fisheries (GC Doc. 07/4) Annex 17. In. Report of the General Council, 24-28 September 2007 Lisbon, Portugal. NAFO, Dartmouth. NAFO GC Doc., No. 5, Serial No. N5478, $73 \mathrm{p}$. 
1979-1980, 1991-2003. NAFO Annual Reports. NAFO, Dartmouth, N.S. http://www.nafo.int/about/annrep/annrep.html

1980-2002. NAFO Scientific Council Reports. Report of the Standing Committee on Fishery Science (STACFIS). Special and Regular Meetings. NAFO, Dartmouth, N.S.http://www.nafo.int/science/reports_html

NL. 2005. Community Accounts. Provincial community statistics. Newfoundland and Labrador. http://www.communityaccounts.ca

OECD. 1997. Towards sustainable fisheries: economic aspects of the management of living marine resources. OECD Publishing, Paris, 268 p.

2000. Transition to responsible fisheries: economic and policy implications. OECD Publishing, Paris, $276 \mathrm{p}$.

PARSONS, D. M. MS 2004. Witch flounder in NAFO divisions 3NO. NAFO SCR Doc., No. 43, Serial No. N4995, $30 \mathrm{p}$.

POWER, D. MS 2003a. An assessment of the status of the redfish in NAFO divisions 3LN. NAFO SCR Doc., No. 55, Serial No. N4873, 21 p.

MS 2003b. An assessment of the status of the redfish in NAFO division 3O. NAFO SCR Doc., No. 63, Serial No. N4882, 30 p.

ROSENBERG, A., M. MOONEY-SEUS, and C. NINNES. 2005. Bycatch on the High Seas: A Review of the Effectiveness of the Northwest Atlantic Fisheries Organization. WWF-Canada, Toronto, Canada. 164p.

RAYFUSE, R. 2005. To Our Children's Children's Children: From Promoting to Achieving Compliance in High Seas Fisheries. Conference on the Governance of High Seas Fisheries and the UN Fish Agreement. Moving from Words to Action. St. John's, Newfoundland and Labrador, May 1 to 5, 2005, 16 p. http://www.dfo-mpo.gc.ca/fgccgp/documents/rayfuse_e.pdf

SCHMIDT, C.-C. 2005. Economic Drivers of Illegal, Unreported, and Unregulated (IUU) Fishing. Conference on the Governance of High Seas Fisheries and the UN Fish Agreement. Moving from Words to Action. St. John's, Newfoundland and Labrador, May 1 to 5, 2005, $25 \mathrm{p}$. http://www.dfo-mpo.gc.ca/fgc-cgp/documents/schmidt_ e.pdf

SEAFOODEXPORT. 2005. Frozen and salted North Atlantic seafood species. Marseilles, France. http://www.seafoodexport.com/site/page/products/pspecies.php

SHELTON, P. MS 2005. Does the rebuilding plan for Greenland halibut in subarea 2 and divisions 3LKMNO have a sufficient scientific basis and is it on track? NAFO SCR Doc. No. 10, Serial No. N5089, 8 p.

SPCFO. 2002. Foreign overfishing: its impacts and solution. Report of the Standing Parliamentary Committee on Fisheries and Oceans. Wayne Easter, M.P., Chair. 19 p.

SSCFO. 1995. Report on the Atlantic groundfish fishery. Overcapacity in the Processing Sector. A Report of the Standing Senate Committee on Fisheries and Oceans, 3 p.

2003. Straddling fish stocks in the northwest Atlantic. A Report of the Standing Senate Committee on Fisheries and Oceans. The Honourable Gerald J. Comeau, Chair. Second Session, Thirty-Seventh Parliament. 79 p.

2005. Minutes of the Standing Senate Committee on Fisheries and Oceans. Witnesses: Mayor Allister H. Hann of the Town of Burgeo, Newfoundland and Labrador, and George Reid, Deputy mayor. The Honourable Gerald J. Comeau, Chair. Second Session, Thirty-Seventh Parliament.

SWAN, J., and D. GRÉBOVAL (eds.). 2005. Overcoming factors of unsustainability and overexploitation in fisheries: selected papers on issues and approaches. International Workshop on the Implementation of the International Fisheries Instruments and Factors of Unsustainability and Overexploitation in Fisheries. Siem Reap, Cambodia, 13-16 September 2004. FAO Fisheries Report, No. 782, $352 \mathrm{p}$.

TFAF. 1982. Navigating troubled waters: a new policy for the Atlantic fisheries. Report of the Task Force on Atlantic Fisheries. Michael J. Kirby, Chairman.

VARELA-LAFUENTE, M., J. S. REGUEIRO, M. D. G. GIL, and A. C. SANTOS. MS 2004. Socio-economic effect of fisheries regulation measures in the NAFO area. Preliminary report. Universidad_Informe Preliminar (20 Mayo). Department of Applied Economy, University of Vigo, $35 \mathrm{p}$.

WOODROW, M. 2004. Vulnerability in coastal communities: adaptation to change and planning for the future. Overview of the Change Islands Workshop. August 23-25, 2003. February. 28 p. 